Atmos. Chem. Phys., 10, 10521-10539, 2010

www.atmos-chem-phys.net/10/10521/2010/

doi:10.5194/acp-10-10521-2010

(c) Author(s) 2010. CC Attribution 3.0 License.

\title{
Aqueous chemistry and its role in secondary organic aerosol (SOA) formation
}

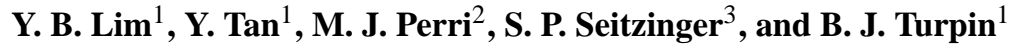 \\ ${ }^{1}$ Department of Environmental Sciences, Rutgers University, New Brunswick, NJ, USA \\ ${ }^{2}$ Department of Chemistry, Sonoma State University, Rohnert Park, CA, USA \\ ${ }^{3}$ Institute of Marine and Coastal Sciences, Rutgers University, Rutgers/NOAA CMER Program, New Brunswick, NJ, USA
}

Received: 22 May 2010 - Published in Atmos. Chem. Phys. Discuss.: 9 June 2010

Revised: 15 October 2010 - Accepted: 7 November 2010 - Published: 10 November 2010

\begin{abstract}
There is a growing understanding that secondary organic aerosol (SOA) can form through reactions in atmospheric waters (i.e., clouds, fogs, and aerosol water). In clouds and wet aerosols, water-soluble organic products of gas-phase photochemistry dissolve into the aqueous phase where they can react further (e.g., with $\mathrm{OH}$ radicals) to form low volatility products that are largely retained in the particle phase. Organic acids, oligomers and other products form via radical and non-radical reactions, including hemiacetal formation during droplet evaporation, acid/base catalysis, and reaction of organics with other constituents (e.g., $\mathrm{NH}_{4}^{+}$).

This paper provides an overview of SOA formation through aqueous chemistry, including atmospheric evidence for this process and a review of radical and non-radical chemistry, using glyoxal as a model precursor. Previously unreported analyses and new kinetic modeling are reported herein to support the discussion of radical chemistry. Results suggest that reactions with $\mathrm{OH}$ radicals tend to be faster and form more SOA than non-radical reactions. In clouds these reactions yield organic acids, whereas in wet aerosols they yield large multifunctional humic-like substances formed via radical-radical reactions and their $\mathrm{O} / \mathrm{C}$ ratios are near 1 .
\end{abstract}

\section{Introduction}

Secondary organic aerosol (SOA) is a major component of atmospheric fine particulate matter $\left[\mathrm{PM}_{2.5}\right.$ ] (Zhang et al., 2007; Aiken et al., 2008), which degrades visibility, causes

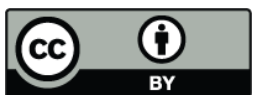

Correspondence to: Y. B. Lim

(ylim@envsci.rutgers.edu) adverse health effects and impacts climate (Seinfeld and Pandis, 1998). The traditional view is that SOA forms through the partitioning of semivolatile products of gas-phase photochemical reactions involving volatile organic compounds (VOCs) and atmospheric oxidants (Seinfeld and Pankow, 2003; Pankow, 1994). In partitioning theory, product volatility, organic mass in preexisting particles and temperature are major factors. Ideally, if the reacted mass of all organic precursors, the vapor pressures of all organic products, the concentration of organic matter in preexisting particles, and temperature were known, SOA formation could be accurately predicted. Partitioning theory is a fundamental tool for modeling SOA (Odum et al., 1996; Seinfeld and Pankow, 2003; Donahue et al., 2006). While clearly important, this traditional view of SOA formation fails to fully explain atmospheric observations: (1) models do not accurately reproduce the magnitude, distribution and dynamics of measured organic aerosol concentrations (Tsigaridis and Kanakidou, 2003; Heald et al., 2005); (2) the oxygen-to-carbon ratio $(\mathrm{O} / \mathrm{C})$ of aged ambient organic aerosol is larger than that of smog chamber SOA (Aiken et al., 2008); (3) in some locations SOA surrogates are more strongly associated with liquid water than with organic matter concentrations in ambient aerosol (Hennigan et al., 2008; Hennigan et al., 2009); and (4) in some locations SOA from biogenic hydrocarbons is positively correlated with anthropogenic tracers despite lower smog chamber yields at high $\mathrm{NO}_{\mathrm{x}}$ concentrations (de Gouw et al., 2008; Weber et al., 2007).

Several recent insights might help to address these gaps in understanding (Robinson et al., 2007; Donahue et al., 2006; Goldstein and Galbally, 2007). Among these is the realization that reactions of condensed semivolatile compounds in/on aerosol particles produce high molecular

Published by Copernicus Publications on behalf of the European Geosciences Union. 
weight organic compounds, including oligomers (Ravishankara, 1997; Jang et al., 2002; Kalberer et al., 2004; Tolocka et al., 2004). Another is the realization that low volatility products, and therefore, SOA can form through aqueous reactions in clouds, fogs and wet aerosols (Blando and Turpin, 2000; Glencser and Varga, 2005; Ervens et al., 2004; Carlton et al., 2006; Volkamer et al., 2007). Water soluble gases react (e.g., via photochemistry, acid catalysis, and with inorganic constituents) in the aqueous phase forming organic acids, oligomers, and organosulfates (Carlton et al., 2006; Guzman et al., 2006; Perri et al., 2010). Lower volatility products are retained, at least in part, in the particle phase after water evaporation (Loeffler et al., 2006; El Haddad et al., 2009). Retention of some compounds (e.g., glyoxal) is enhanced by hemiacetal formation during water evaporation (Loeffler et al., 2006).

In this paper, using glyoxal as an example SOA precursor, we discuss atmospheric evidence for SOA formation through aqueous chemistry. We then synthesize the current literature, providing a more comprehensive picture of SOA formation through aqueous chemistry. We use this understanding and kinetic modeling to discuss new results from aqueous reactions of glyoxal $(30-3000 \mu \mathrm{M})$ with and without $\mathrm{OH}$ radicals $\left(\sim 10^{-12} \mathrm{M}\right)$. Based on these insights we discuss similarities and differences between SOA formation through aqueous-phase reactions in clouds (glyoxal concentration $\sim 1-300 \mu \mathrm{M}$; Munger et al., 1990) and in wet aerosol ( 1-10 M; Volkamer et al., 2009). At aerosol-relevant concentrations, we predict that oligomers and other humic-like substances (HULIS) are the dominant products and that these form through organic radical-radical reactions. This is, to our knowledge, new chemistry to form SOA.

\section{Methods: new analyses and kinetic modeling}

The radical reaction section of this paper draws heavily on bulk experiments of $\mathrm{OH}$ radical-initiated reactions of glyoxal in the aqueous phase described in detail by Tan et al. (2009) and includes previously unreported analyses of these samples by ultra high resolution Fourier Transform Ion Cyclotron Resonance electrospray ionization mass spectrometry (FTICR-MS) and new kinetic modeling.

\subsection{FTICR-MS}

Samples from aqueous photooxidation experiments (Tan et al., 2009) were analyzed by FTICR-MS (Thermo-Finnigan LTQ-XL, Woods Hole Oceanographic Institute Mass Spectrometer Facility). These samples were frozen at $-20^{\circ} \mathrm{C}$ for later FTICR-MS analysis (Perri et al., 2009, 2010).

Experiments were conducted at cloud relevant and higher concentrations, but concentrations were still several orders of magnitude lower than in wet aerosol. Briefly, glyoxal $(30,300$, and $3000 \mu \mathrm{M})$ was dissolved in $18 \mathrm{M} \Omega$ milli-Q wa- ter. OH radicals $\left(\sim 10^{-12} \mathrm{M}\right)$ were generated by photolysis (254 mm Hg UV lamp) of hydrogen peroxide (initial concentration $=$ five times the concentration of glyoxal). Reaction temperature was maintained at $\sim 25^{\circ} \mathrm{C}$, via water jacket; $\mathrm{pH}$ decreased from 5 to $\sim 3$ over the course of the $200 \mathrm{~min}$ experiments. Selected samples were also analyzed by ion chromatography (IC) for quantification of organic acids and electrospray ionization mass spectrometry (ESI-MS) for temporal behavior at unit mass resolution. In order to verify that products formed by $\mathrm{OH}$-radical reactions with glyoxal, control experiments were conducted including glyoxal + UV, glyoxal $+\mathrm{H}_{2} \mathrm{O}_{2}\left( \pm \mathrm{H}_{2} \mathrm{SO}_{4}\right), \mathrm{H}_{2} \mathrm{O}_{2}+\mathrm{UV}\left( \pm \mathrm{H}_{2} \mathrm{SO}_{4}\right)$, mixed standard $+\mathrm{H}_{2} \mathrm{O}_{2}$, and mixed standard + UV. Mixed standards contained glyoxal, oxalic, glyoxylic, malonic, succinic, formic and glycolic acids.

\subsection{Kinetic modeling}

Using the reaction mechanism for glyoxylic acid/oxalic acid formation and radical-radical reactions to form larger acid and oligomers, we developed a full kinetic model to explore the aqueous chemistry of glyoxal and $\mathrm{OH}$ radical at cloud and aerosol-relevant concentrations. Most of the kinetic rate constants were obtained from literature documented in Tan et al. (2009), or determined using an estimation method based on the structure-activity relationship (Monod et al., 2005, 2008). For the radical- $\mathrm{O}_{2}$ and the radical-radical reactions, the rate constants of $1 \times 10^{6} \mathrm{M}^{-1} \mathrm{~s}^{-1}$ and $1.3 \times 10^{9} \mathrm{M}^{-1} \mathrm{~s}^{-1}$ suggested by Guzman et al. (2006) were used. In a few cases rate constants were fit to experimental measurements from Tan et al. (2009). Details are provided in Supplementary Information. All the rate constants and equilibrium constants are listed in Table S1 (Supplement). The model was validated by comparing model simulations with experimental results (Tan et al., 2009). Both simulated $\mathrm{OH}$ concentrations (1$\left.7 \times 10^{-12} \mathrm{M}\right)$ and simulated and measured $\mathrm{pH}(\sim 3-5)$ reasonably reflect cloud conditions (Lim et al., 2005; Carlton et al., 2006). Atmospheric waters are expected to be saturated with dissolved $\mathrm{O}_{2}$ because the surface-to-volume ratio of cloud droplets and wet aerosols is very high. In $3000 \mu \mathrm{M}$ glyoxal simulations dissolved $\mathrm{O}_{2}$ remains saturated $(\sim 0.3 \mathrm{mM})$ and the model predicts the dimer formation via radical-radical reactions (Fig. S1).

\section{Atmospheric evidence}

SOA formed through atmospheric aqueous chemistry is a strong candidate for closing the gap between the measured organic aerosol and atmospheric model predictions in part because it is formed from different precursors. In traditional SOA (formed via vapor pressure driven partitioning), precursors must be large $\left(>\mathrm{C}_{7}\right)$ to produce semivolatile products with high yields (Seinfeld and Pankow, 2003). In contrast, aqueous SOA precursors tend to be small (e.g., $\mathrm{C}_{2}, \mathrm{C}_{3}$ ) 
because they must be water soluble (Volkamer et al., 2007). Glyoxal, methylglyoxal, glycolaldehyde, and pyruvic acid are too volatile to be good precursors of traditional SOA. Yet they have been observed or are predicted to form low volatility products in the aqueous phase (Tan et al., 2009; Altieri et al., 2008; Perri et al., 2009; Carlton et al., 2006; Volkamer et al., 2009). Although the uncertainties are large, regional (northeastern USA) and global chemical transport modeling suggests that SOA formed through aqueous chemistry is comparable in a magnitude to that formed through the traditional pathway (Chen et al., 2007; Carlton et al., 2008; Fu et al., 2008, 2009).

The observation that ambient oxygenated organic aerosol (OOA; a surrogate for SOA) has higher $\mathrm{O} / \mathrm{C}$ ratios and organic mass to organic carbon ratios $(\mathrm{OM} / \mathrm{OC})$ than does SOA formed in smog chambers (Aiken et al., 2008) provides strong evidence for SOA formation through aqueous chemistry. Aiken et al. (2008) report $\mathrm{O} / \mathrm{C}$ ratios of $\sim 0.8-1.0$ and $0.5-0.6$ for the oxygenated fractions of ambient organic aerosol called OOA-1 and OOA-2, respectively $\left(\mathrm{OM} / \mathrm{OC}_{\mathrm{MAX}}=2.5\right)$, whereas $\mathrm{O} / \mathrm{C}$ ratios observed for smog chamber SOA were only $0.27-0.43$. Similarly, high OM/OC ratios for the water soluble fraction of aged ambient organic aerosol have been reported (e.g., $\mathrm{OM} / \mathrm{OC}=2.1$, Turpin and Lim, 2001; OM/OC = 2.54, Polidori et al., 2008). O/C ratios $\sim 0.4$ for smog chamber SOA are to be expected because for compounds with high carbon number $\left(>\mathrm{C}_{7}\right)$ only a few steps in the oxidation process (i.e., addition of two or three functional groups in the precursor carbon chain) are needed for products to partition into the particle phase (Lim and Ziemann, 2005; Lim and Ziemann, 2009c). Decomposition (fragmentation) of the carbon chain inhibits condensation for highly branched precursors (Lim and Ziemann, 2009a). On the other hand, SOA formed through aqueous chemistry has $\mathrm{O} / \mathrm{C}$ ratios of $\sim 1-2$ (OM/OC $\sim 2.5-3.8)$ because oxidation occurs on precursors with low carbon numbers. Oxalic acid has the highest $\mathrm{O} / \mathrm{C}$ ratio of $2(\mathrm{OM} / \mathrm{OC}=3.8)$. Oligomers have been shown to form in the aqueous phase from photolysis and/or $\mathrm{OH}$ radical oxidation of glyoxal (Tan et al., 2009), methylglyoxal (Altieri et al., 2008), glycolaldehyde (Perri et al., 2009), pyruvic acid (Guzman et al., 2006; Altieri et al., 2006), and phenolic compounds (Sun et al., 2010). The oligomeric methylglyoxal, glycolaldehyde, and phenolic products have been characterized; they have an average $\mathrm{O} / \mathrm{C}$ ratio of $\sim 0.7-1.1$ (average $\mathrm{OM} / \mathrm{OC}=2.0-2.6$; Altieri et al., 2008; Perri et al., 2009; Sun et al., 2010). Water evaporation also forms glyoxal oligomers with $\mathrm{O} / \mathrm{C}$ ratios $\sim 1-1.5$ (Loeffler et al., 2006).

The high $\mathrm{O} / \mathrm{C}$ ratios formed from aqueous photochemistry in laboratory studies are similar to the measured $\mathrm{OM} / \mathrm{OC}$ of $2.5(\mathrm{O} / \mathrm{C} \sim 1)$ for the water-soluble fraction of ambient organic aerosol samples fractionated by polarity (Pittsburgh, PA; Polidori et al., 2008) and to the ambient $\mathrm{O} / \mathrm{C}$ ratios observed for the quantity defined as OOA-1 in the Aerosol Mass Spectrometer $\left(\mathrm{O} / \mathrm{C}_{\mathrm{MAX}}=1.0 ; \mathrm{OM} / \mathrm{OC}=2.5\right)$. Thus, we hypothesize that OOA-1 (also called low volatility OOA Jimenez et al., 2009) is a surrogate for SOA formed through aqueous phase reactions. This aerosol material has the potential to act as cloud condensation nuclei $(\mathrm{CCN})$. Interestingly, studies of CCN activity suggest that chemical aging processes conducted in smog chambers do not oxidize organic aerosols to the level needed for wet scavenging (Petters et al., 2006; Varubangkul et al., 2006).

In Mexico City, Volkamer et al. (2007) discovered an unanticipated sink for gas-phase glyoxal and suggested that the "missing" glyoxal partitioned into aerosol liquid water and formed SOA via aqueous chemistry. In later chamber experiments they observed SOA formation from glyoxal in the presence of preexisting particles at high humidity (Volkamer et al., 2009). Moreover, SOA formation was dramatically enhanced under irradiated conditions (when $\mathrm{OH}$ radical was present). This strongly suggests that aqueous photooxidation is important to formation of glyoxal SOA.

SOA formation through aqueous chemistry is also consistent with reports that SOA in Atlanta, Georgia increased linearly with aerosol water concentrations but showed no dependence on the particulate organic carbon concentration (Hennigan et al., 2008; Hennigan et al., 2009). In Atlanta, particle-phase water soluble organic carbon (WSOC) is considered to be a good surrogate for SOA and comprises $\sim 75 \%$ of total particulate organic carbon (Sullivan and Weber, 2006; Weber et al., 2007). Hennigan et al. (2008) found that the fraction of WSOC in the particle phase increases abruptly when RH is higher than $70 \%$. The increase was greater than expected based on Henry's law partitioning alone, suggesting that partitioning was enhanced by subsequent aqueous phase reactions or other considerations. The positive association with liquid water rather than with organic matter (Hennigan et al., 2009) suggests that aqueous reactions, rather than partitioning of semivolatile gas-phase products, was the dominant SOA formation pathway in this location.

The positive correlation of "biogenic" SOA with anthropogenic tracers in Atlanta and the northeastern US (Weber et al., 2007; de Gouw et al., 2008) could be explained by aqueous chemistry. In those studies, particulate WSOC, a surrogate for SOA, was predominantly formed from biogenic hydrocarbons such as isoprene as evidenced by radiocarbon analysis. Yet the resulting SOA was strongly correlated with $\mathrm{CO}$ and isopropyl nitrate, anthropogenic combustion tracers. This was not expected because yields of isoprene SOA formed in smog chamber experiments decrease with increasing concentrations of $\mathrm{NO}_{\mathrm{x}}$, another anthropogenic combustion tracer (Kroll et al., 2006). However, this finding is consistent with the fact that higher isoprene SOA yields are expected at high $\mathrm{NO}_{\mathrm{x}}$ when aqueous chemistry is involved (Ervens et al., 2008). This is because the gas-phase photooxidation of isoprene at high $\mathrm{NO}_{\mathrm{x}}$ produces more water soluble carbonyl compounds, such as methylglyoxal, glycolaldehyde, and glyoxal. Anthropogenically-influenced particles 
might also contain more sulfate and therefore have higher liquid water contents, providing the medium for aqueous chemistry. To the extent that the observed association between anthropogenic pollutants and biogenic SOA is causal, biogenic SOA is not natural (Carlton et al., 2010).

SOA formation through aqueous chemistry in clouds and wet aerosols requires the following: (1) hygroscopic particles or CCN, (2) high $\mathrm{RH}(>70 \%)$ to enable (3) the partitioning of water soluble organic gases into the aerosol or cloud water, and (4) chemistry that yields lower volatility products which remain in the particle phase even after water evaporation. SOA formation through aqueous chemistry is most likely to occur when conditions favor gas phase photochemistry (producing water-soluble compounds and oxidants) and high humidity.

\section{Aqueous chemistry of glyoxal}

Glyoxal is the simplest and one of the most abundant dicarbonyls in the atmosphere (Volkamer et al., 2001), with an estimated source of $45 \mathrm{Tg}$ annually (Fu et al., 2008). It is formed from the photooxidation of both anthropogenic VOCs like aromatic hydrocarbons (Jang and Kamens, 2001) and biogenic VOCs like isoprene (Atkinson et al., 2006). The presence of glyoxal in the air above the Pacific Ocean suggests that there is also a marine source (Warneck, 2003). Although gas-phase photolysis and photooxidation are major sinks (Atkinson, 2000; Volkamer et al., 2005; Tadic et al., 2006; Myriokefalitakis et al., 2008; Fu et al., 2008), glyoxal has great potential to form SOA through aqueous-phase reactions in clouds and wet aerosols, due to its high water solubility, ability to form oligomers via acid catalysis, and reactivity with $\mathrm{OH}$ radicals (Blando and Turpin, 2000; Volkamer et al., 2007; Carlton et al., 2007).

\subsection{Glyoxal uptake by water}

The uptake or solubility of glyoxal depends on its reactivity in and the composition of the atmospheric waters. Glyoxal is highly water soluble due to the hydration of both aldehyde groups (Fig. 1), with an effective Henry's law constant, $K^{*} \mathrm{H}$ of $4.2 \times 10^{5} \mathrm{M} \mathrm{atm}^{-1}$ in pure water (Ip et al., 2009) and $3.6 \times 10^{5} \mathrm{M} \mathrm{atm}^{-1}$ in bulk seawater (Zhou and Mopper, 1990). The solubility in aerosol water is expected to be further enhanced because of the presence of concentrated inorganic/organic solutes (Saxena et al., 1995). An effective Henry's law constant, $K^{*}{ }_{\mathrm{H}}$ of $2.6 \times 10^{7} \mathrm{M} \mathrm{atm}^{-1}$ for ammonium sulfate seed particles at $\sim 50 \% \mathrm{RH}$ was measured, and this enhancement is likely due to the ionic strength (Kroll et al., 2005) or the formation of the inorganic-organic complexes (Zhang et al., 2009). Comparable uptake, expressed as a Henry's constant, was reported for wet ammonium sulfate seed particles (46-86\% RH) exposed to glyoxal and $\mathrm{OH}$ radicals in a smog chamber (Volkamer et al., 2009; Ervens and Volkamer, 2010). It should be noted that $\mathrm{OH}$ radical reactions are considered irreversible, and are not intended to be described by Henry's equilibrium partitioning constants. Reactive uptake of glyoxal through aqueous reactions with photochemical oxidants could be substantially greater in the atmosphere where summertime photochemistry takes place more than 12-h per day.

\subsection{Aqueous-phase reactions of glyoxal: overview}

Dissolved glyoxal could undergo several types of reactions in atmospheric waters leading to products that will remain, at least in part, in the particle phase. Aqueous-phase reactions can be categorized as radical reactions and non-radical reactions. Radical reactions can involve a variety of atmospheric oxidants, including $\mathrm{OH}$ radicals, $\mathrm{NO}_{3}$ radicals, $\mathrm{O}_{3}$, and can be initiated by photolysis. During the daytime, $\mathrm{OH}$ radicals are considered to be the most important to glyoxal chemistry because their atmospheric abundance, reactivity, and water solubility are high. In the atmosphere the major limitation for aqueous reactions of glyoxal with $\mathrm{OH}$ radicals is the competition with rates of gas-phase photolysis/photooxidation of glyoxal. The smog chamber experiments of Volkamer et al. (2009) suggest that gas-phase reactions of glyoxal with $\mathrm{OH}$ radicals are not likely to limit glyoxal uptake into the aqueous-phase reactions. Gas-phase $\mathrm{OH}$ radicals are the major source of $\mathrm{OH}$ radicals in atmospheric waters (Faust and Allen, 1993). They are primarily available during the daytime with a gas-phase concentration of $\sim 2 \times 10^{6}$ molecule $\mathrm{cm}^{-3}$ (12-h daytime average) (Finlayson-Pitts and Pitts, 2000), and Henry's law constant of $30 \mathrm{M} \mathrm{atm}^{-1}$ (Warneck, 1999). In the chamber study of Volkamer et al. (2009), conducted with an $\mathrm{OH}$ radical concentration of $\sim 10^{7}$ molecule $\mathrm{cm}^{-3}$, SOA formation through aqueous photooxidation of glyoxal was dramatic. In the atmosphere, $\mathrm{OH}$ radicals are also formed in the aqueous phase through the photolysis of $\mathrm{H}_{2} \mathrm{O}_{2}$ and photo-Fenton reactions (i.e., $\mathrm{Fe}^{2+}+\mathrm{H}_{2} \mathrm{O}_{2}+h v \rightarrow \mathrm{Fe}^{3+}+\mathrm{OH}^{-}+\mathrm{OH}$ ) (Arakaki and Faust, 1998). From these channels the Lim model (Lim et al., 2005; using conditions described therein) predicts that roughly one third of aqueous-phase $\mathrm{OH}$ radicals in clouds are formed in the aqueous phase. A detailed discussion of $\mathrm{OH}$ radical reactions is provided later (Sect. 6). Non-radical reactions include hemiacetal formation (Liggio et al., 2005a; Loeffler et al., 2006), aldol condensation (Jang et al., 2002; Kalberer et al., 2004; Noziere and Cordova, 2008; Shapiro et al., 2009), imine formation (De Haan et al., 2009a; De Haan et al., 2009b; Galloway et al., 2009), anhydride formation (Gao et al., 2004), esterification via condensation reactions (Gao et al., 2004; Surratt et al., 2006, 2007; Altieri et al., 2008), and organosulfate formation (Liggio et al., 2005b; Surratt et al., 2007).

Both "chamber experiments" and "bulk experiments" have been used to investigate the atmospheric aqueous chemistry of glyoxal. Chamber experiments are conducted in a Teflon 


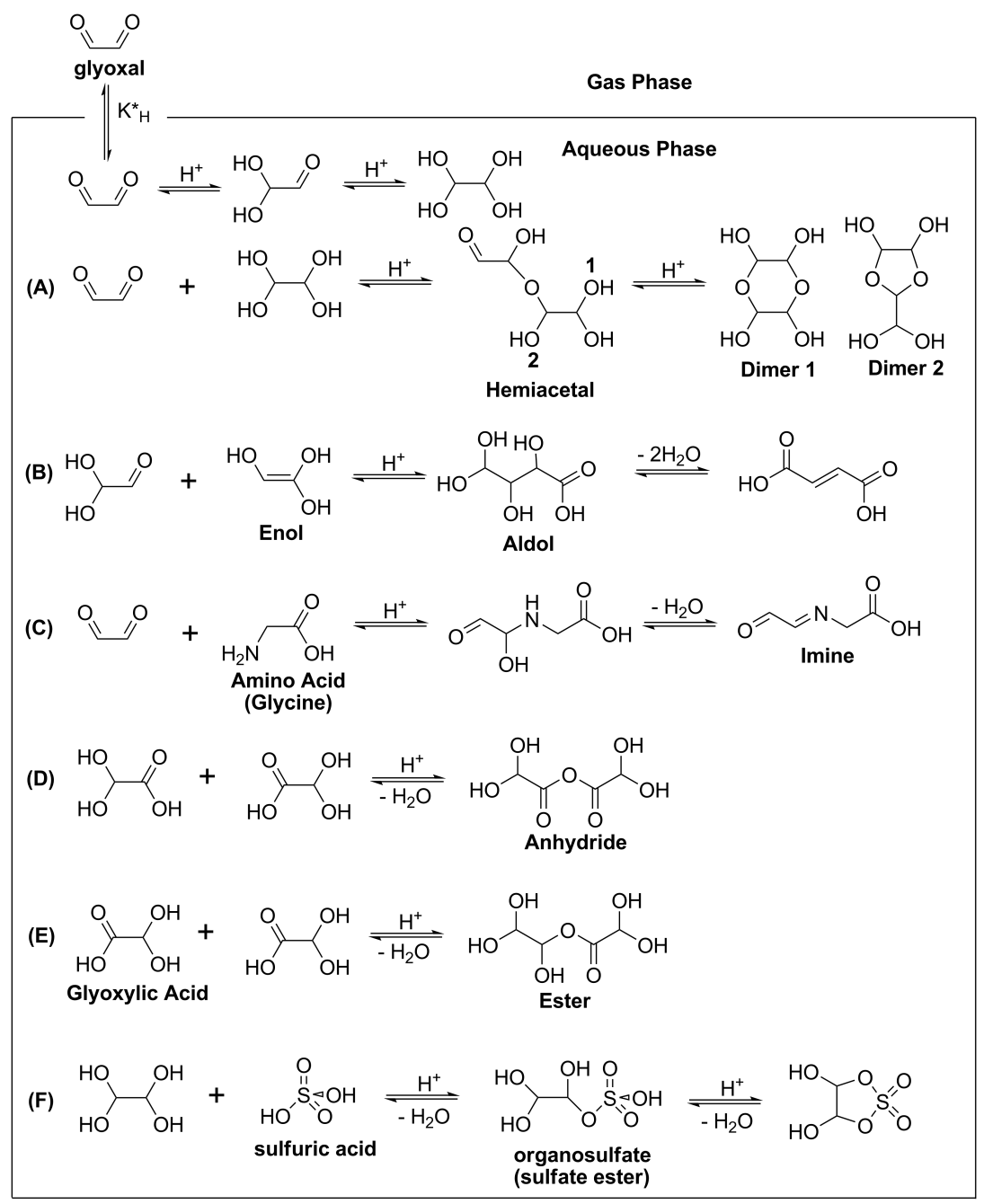

Fig. 1. Glyoxal partitioning (governed by effective Henry's law, $K^{*} \mathrm{H}$ ), hydration, acid catalysis to form hemiacetal (A), aldol (B), imine (C), anhydride (D), ester (E) and organosulfate (F). For (A), glyoxal and hydrated glyoxal form Dimer 1 and 2 depending on which OH group (1 or 2) attacks a carbon in the carbonyl group.

chamber filled with dry clean air (typically $<\sim 5 \% \mathrm{RH})$. To study glyoxal chemistry, seed particles (e.g., ammonium sulfate), water soluble organic compounds (e.g., glyoxal) and water vapor are added to the chamber. Water vapor is added to increase the humidity above the deliquescence point, so that liquid water is present in/on the seed particles. For photooxidation, $\mathrm{OH}$ radicals are typically generated by photolysis of either hydrogen peroxide or methyl nitrite with NO. An advantage of the chamber experiments is that gas-phase reactions, partitioning, aqueous-phase reactions in wet aerosols, and SOA formation can be investigated in a single integrated system. In contrast, it is easier to study the detailed aqueous chemistry in bulk experiments. Bulk experiments are conducted in a reaction vessel or vial with water soluble organic compounds, inorganic compounds (e.g., ammonium sulfate, sulfuric acid) and water. $\mathrm{OH}$ radicals are generated by photolysis of hydrogen peroxide. Cloud-relevant and aerosol- relevant conditions can be studied and sample availability is not limited for chemical analyses. For further investigation of cloud processing, droplets formed from bulk samples can be evaporated (Ed Haddad et al., 2009; De Haan et al., 2009c; Loeffler et al., 2006).

\section{Non-radical chemistry}

\subsection{Hemiacetal formation}

The currently accepted view is that self oligomerization of glyoxal occurs via hemiacetal formation (Loeffler et al., 2006) and that of methylglyoxal occurs via aldol condensation (De Haan et al., 2009a). Glyoxal molecules by themselves form oligomers through acid catalyzed hemiacetal formation during water evaporation from cloud droplets 
(Loeffler et al.2006) or glyoxal uptake in wet aerosols (Liggio et al., 2005a). During evaporation some hydrated glyoxal dehydrates, forming singly hydrated or dehydrated glyoxal, and reacts with remaining hydrated glyoxal to form a hemiacetal as shown in Fig. 1a (Loeffler et al., 2006). Briefly, a carbonyl group in glyoxal is protonated by $\mathrm{H}^{+}$, then a hydroxyl group in the hydrated glyoxal attacks the protonated carbonyl to form a hemiacetal. The second acid catalysis occurs intermolecularly so that dimer 1 or 2 is formed, depending on which hydroxyl group ( 1 or 2 ) attacks.

\subsection{Aldol condensation}

Jang et al. (2002) first proposed oligomerization of organic carbonyls through aldol condensation on the wet surface of the particle. While aldol condensation of glyoxal was not considered likely by Barsanti and Pankow (2005), Shapiro et al. (2009) reported this possibility based on the observation of pi-conjugated systems suggested by the analyses of UVVis spectra, density functional theory, and a kinetic model study. They noted that the observed absorption above 400 $\mathrm{nm}$ could be due to pi-conjugated system formation. Alternatively imines (or C-N containing organic compounds) from reactions involving ammonium could be responsible for the UV-Vis absorption observed by Shapiro et al. Aldol condensation of glyoxal would involve the reaction of an enol tautomer of monohydrated glyoxal with dehydrated glyoxal (Fig. 1b) and nucleophilic addition of the enol to the carbonyl in the dehydrated glyoxal. Note, a cloud-relevant bulk experiment suggested that major oligomerization of methylglyoxal occurs via hemiacetal formation at $\mathrm{pH} 3$ and via aldol condensation at $\mathrm{pH} 4$ (Yasmeen et al., 2009). Sareen et al. (2010) observed both hemiacetal and aldol condensation products from methylglyoxal oligomerization. It appears that both glyoxal and methylglyoxal can undergo hemiacetal formation and aldol condensation (Schwier et al., 2010) and the chemistry could be $\mathrm{pH}$ dependent.

Oligomer formation via acid catalysis (hemiacetal formation or aldol condensation) can also occur via a catalyst other than $\mathrm{H}^{+}$. For example, acetalaldehyde has been reported to form oligomers through amino acid catalyzed (Noziere and Codova, 2008) and ammonium ion (Noziere et al., 2009a, b; 2010) catalyzed aldol condensation. Noziere et al. (2009b) also reported that glyoxal oligomerization was enhanced by the presence of ammonium ions. Ammonium catalysis is a variant of acid catalysis. $\mathrm{NH}_{4}^{+}$dissociates to $\mathrm{NH}_{3}$ and $\mathrm{H}^{+}$. The reaction is initiated by $\mathrm{H}^{+}$catalysis. $\mathrm{NH}_{3}$ then either acts as a reactant to form imines or as a catalyst to form aldol condensation products. Noziere et al. (2009a, b, 2010) argue that $\mathrm{NH}_{4}^{+}$catalysis is a major source of oligomers in wet aerosols.

\subsection{Imine formation}

Imines (including imidazoles) are key products in the reaction of glyoxal with ammonium, amino acid, and amine, since they react further with themselves or glyoxal to form CN containing oligomers (De Haan 2009a, b; Galloway et al., 2009; Noziere et al., 2009b, 2010). Briefly, imine is formed by the nucleophilic attack by the amine group in amino acid (or amine) to the carbonyl in glyoxal (Fig. 1c). In the presence of amino acids and glyoxal, imine formation is likely to occur during cloud droplet evaporation and in wet acidic aerosols.

\subsection{Anhydride formation}

An anhydride can also form from the reaction of two carboxylic acids and a loss of water. Anhydride formation occurs by nucleophilic attack by an hydroxyl group in one acid to the carbonyl group in the other, followed by dehydration (Fig. 1d). Gao et al. (2004) reported anhydride products from hydrocarbon ozonolysis in a chamber.

\subsection{Esterification}

Esters are formed by the acid catalyzed condensation reaction of a carboxylic acid with an alcohol (also known as "Fischer esterification"). Figure 1e illustrates the self reaction of glyoxylic acid by esterification; glyoxylic acid is the first generation product of the $\mathrm{OH}$-initiated reaction of glyoxal (Fig. 2), and has both acid and alcohol functional groups. Briefly, the carbonyl in carboxylic acid is protonated by acid catalysis, which allows for nucleophilic attack by the hydroxyl group in the alcohol. An ester is formed after loss of water. Gao et al. (2004) conducted a chamber study of SOA formation by hydrocarbon ozonolysis, and proposed one of the products was an ester based on the detected fragments in the mass spectra. Later, Altieri et al. (2008) concluded that oligoesters formed from aqueous reactions of methylglyoxal with $\mathrm{OH}$ radicals based on ESI-MS-MS fragmentation patterns. While Altieri et al. (2008) proposed that these products formed via condensation reactions, the ester oligomers were only formed in the presence of $\mathrm{OH}$ radicals and not in the absence of $\mathrm{OH}$ radicals. This raises the possibility that such esters form through radical-radical reactions.

\subsection{Organosulfate formation}

Organosulfate (sulfur ester) can form by the acid catalyzed reaction of an alcohol with sulfuric acid, followed by dehydration (Fig. 1f) and by radical-radical reactions (Perri et al., 2010). The reaction of glyoxal with sulfuric acid was reported in a chamber study (Liggio et al., 2005b). Surratt et al. (2007) observed organosulfate products from the chamber experiments of terpene/isoprene photooxidation with seed particles acidified by sulfuric acid. Those two studies propose organosulfate formation via acid catalysis. However, in 


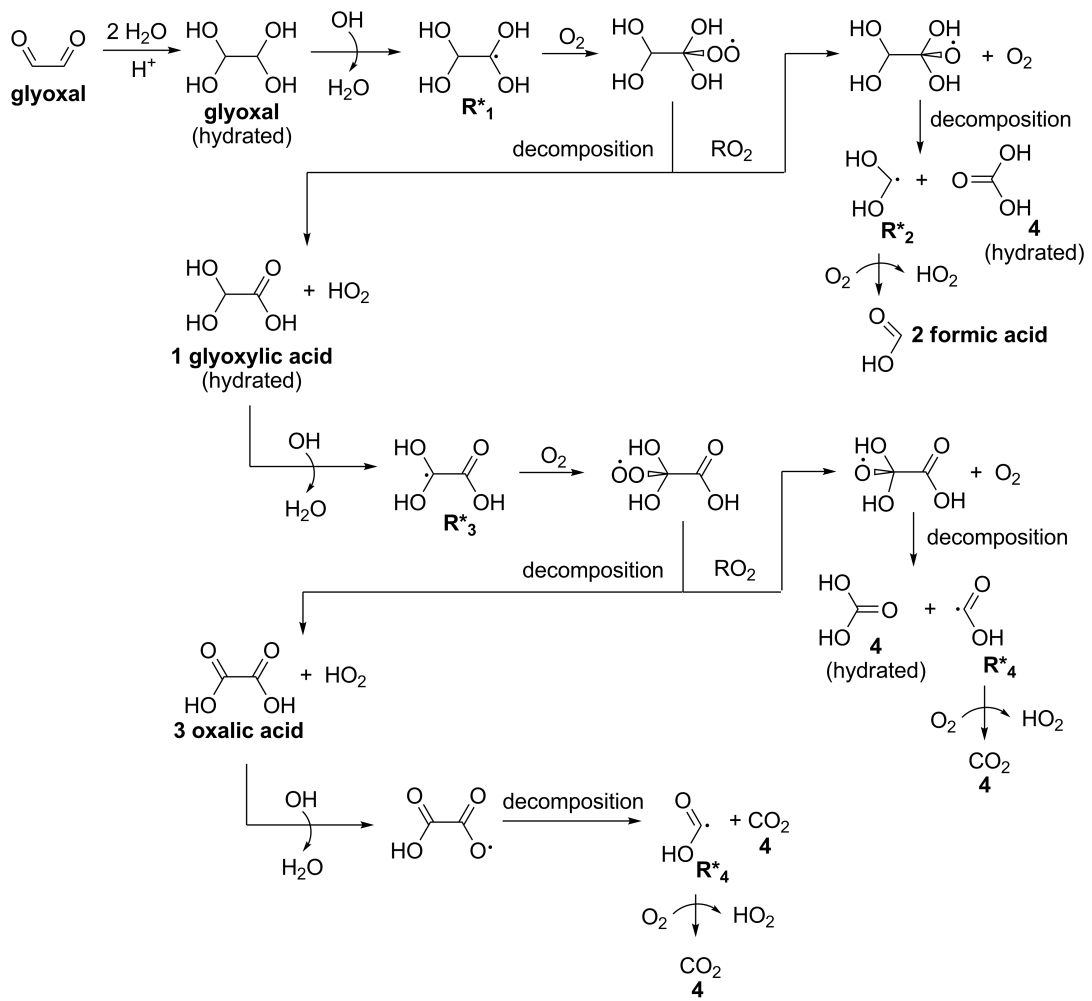

Fig. 2. Mechanism for aqueous-phase reaction of glyoxal with $\mathrm{OH}$ radicals.

bulk glycolaldehyde photooxidation experiments conducted in the presence of sulfuric acid, Perri et al. (2010) found organosulfate products that formed in the presence of $\mathrm{OH}$ radical but not in the absence of $\mathrm{OH}$ radical; they concluded that these formed via radical-radical reactions. Similarly, Galloway et al. (2009) and Noziere et al. (2010) reported that organosulfate formed only under irradiated conditions. These studies also provide strong evidence for radical-radical reactions.

\subsection{Discussion of acid catalyzed pathways to form oligomers}

In this section, we use the existing literature to examine factors affecting SOA formation through non-radical pathways in atmospheric waters (Fig. 1). We discuss currently debated issues such as the role of acidity and ionic strength on reactive uptake of glyoxal and whether these glyoxal oligomers are reversibly formed. It should be emphasized that SOA formation through aqueous chemistry is an intricate dynamic system that is also affected by water solubility, hydration, concentration, and aqueous-phase reactions.

\subsection{Acidity effect on SOA formation}

The current understanding is that glyoxal selfoligomerization in water occurs via acid catalyzed hemiacetal formation. This is consistent with the observation that oligomer formation is reduced when sodium hydroxide is added (Loeffler et al., 2006). However, several studies report that the acidity of the seed particle has an insignificant effect on glyoxal uptake (Kroll et al., 2005; Loeffler et al., 2006; Volkamer et al, 2009) or even on methylglyoxal uptake (Zhao et al., 2006). Although Liggio et al. (2005a) reported increased particle growth by glyoxal uptake with increasing seed particle acidity, the reactive uptake coefficient stays in the same order of magnitude $(2.2-7.3) \times 10^{-3}$ for $\mathrm{pH} 0.9$ to 5.3. In fact, the reactive uptake coefficient at $\mathrm{pH} 1.3$ and $98 \% \mathrm{RH}\left(7.3 \times 10^{-3}\right)$ is higher than that at $\mathrm{pH} 0.9$ and $89 \%$ RH $\left(4.8 \times 10^{-3}\right)$. Thus, it is difficult to conclude there is a strong correlation between the reactive uptake and acidity. This is consistent with reports that the equilibrium constant for glyoxal dimerization is independent of $\mathrm{pH}$ and ionic strength (Fratzke and Reilly, 1986); these authors also found that the rates of dimerization and de-dimerization decrease at low $\mathrm{pH}$. It should be noted that the lack of an acidity effect does not rule out the reactive uptake of glyoxal via acid catalyzed reaction (Kroll et al., 2005; Loeffler et al., 2006), but indicates the effect of acidity on glyoxal uptake is minor. 
Hemiacetal formation requires that hydrated glyoxal and dehydrated glyoxal coexist in the aqueous phase. In order for coexistence, the concentration of dissolved glyoxal must be high in the aqueous phase (Hastings et al., 2005). In the cloud-relevant experiments by Loeffler et al. (2006), water evaporation increases the concentration of glyoxal near the droplet surface. This shifts the equilibrium so that dihydrated glyoxal becomes singly hydrated or even unhydrated. This (partially) dehydrated glyoxal, then, either reacts with bulk hydrated glyoxal to form oligomers or evaporates to maintain Henry's law equilibrium (Fig. 1a). Hastings et al. (2005) observed oligomer formation and no significant evaporation of dehydrated glyoxal while drying water solutions. In the aerosol-relevant experiments by Liggio et al. (2005a), the condensed phase concentration of glyoxal increases because of glyoxal uptake instead of water evaporation. In this experiment, again, the acid catalyzed reaction to form a hemiacetal competes with the evaporation of dehydrated glyoxal (Liggio et al., 2005a). Therefore, the Loeffler et al. (2006) and Liggio et al. (2005a) experiments suggest that oligomer formation during cloud droplet evaporation and in aerosol water is fast compared to the evaporation of dehydrated glyoxal and de-oligomerization is slow, allowing oligomers to stabilize.

While oligomer formation via acid catalyzed reactions appears to be fast, the key question is, "Is the acidity a major factor driving glyoxal uptake in atmospheric particles?" In the chamber study by Volkamer et al. (2009) SOA formation was strongly correlated with aerosol liquid water content (LWC), and not with acidity. They reported $\sim 2 \%$ yield for $3 \mu \mathrm{g} / \mathrm{m}^{3} \mathrm{LWC}$ and $\sim 7 \%$ yield for $5 \mu \mathrm{g} / \mathrm{m}^{3} \mathrm{LWC}$ using the same seed particles composed of ammonium sulfate and fulvic acid so that acidity decreased as LWC increased. This implies that liquid water is a more important factor for glyoxal uptake than acidity (Zhao et al., 2006).

\subsection{Ionic strength and glyoxal-solvent anion interaction}

Glyoxal solubility is affected by ionic strength. Ip et al. (2009) reported that the effective Henry's constant $\left(K^{*}{ }_{H}\right)$ of glyoxal in $\mathrm{NaCl}$ solutions is an order of magnitude higher that that in pure water $\left(4.2 \times 10^{5} \mathrm{Matm}^{-1}\right)$. They also observed that a further increase in ionic strength from $0.05 \mathrm{M}$ to $4.0 \mathrm{M}$ in $\mathrm{NaCl}$ solutions, the effective Henry's constant decreases from $1.9 \times 10^{6} \mathrm{M} \mathrm{atm}^{-1}$ to $8.5 \times 10^{5} \mathrm{M} \mathrm{atm}^{-1}$ : this is known as "salting-out effect". However, they also point out that $K_{\mathrm{H}}^{*}=2.4 \times 10^{7} \mathrm{M} \mathrm{atm}^{-1}$ in $\mathrm{Na}_{2} \mathrm{SO}_{4}$ solutions with the ionic strength of $0.03 \mathrm{M}$ is an order of magnitude higher than $K^{*} \mathrm{H}$ in $\mathrm{NaCl}$ solutions with similar ionic strength of $0.05 \mathrm{M}\left(K^{*}{ }_{\mathrm{H}}=1.9 \times 10^{6} \mathrm{M} \mathrm{atm}^{-1}\right)$. Interestingly, $K^{*} \mathrm{H}$ for the $\mathrm{Na}_{2} \mathrm{SO}_{4}$ solution is very close to what Kroll et al. (2005) measure, $K^{*}{ }_{\mathrm{H}}=2.6 \times 10^{7} \mathrm{M} \mathrm{atm}^{-1}$, for glyoxal uptake by ammonium sulfate seed particles. Although Kroll et al. (2005) conclude that the enhanced uptake is due to the ionic strength, the findings of Ip et al. (2009) suggest that sulfate ions affect the uptake more significantly than chloride ions in solutions with the similar ionic strength.

These differences in glyoxal uptake in solutions with similar ionic strength must be explained by differences in the interaction between glyoxal and the solvent anion (chloride/sulfate ion). In the $\mathrm{NaCl}$ solutions, as Ip et al. (2009) point out, glyoxal uptake is driven by a weak dipole-ionic bonding between $\mathrm{OH}$ functional groups in hydrated glyoxal and the chloride ion. The weakness of this $\left[\mathrm{C}-\mathrm{OH}-\mathrm{Cl}^{-}\right]$ causes the salting-out effect because at high concentration chloride ions interact more with water molecules to form hydration shell, which inhibits the glyoxal-chloride interaction. Although Ip et al. have yet to explain the interaction between glyoxal and sulfate ion in the $\mathrm{Na}_{2} \mathrm{SO}_{4}$ solutions, it is very likely that the larger $K^{*}{ }_{\mathrm{H}}$ is due to stronger hydrogen bonding between $\mathrm{OH}$ functional groups in hydrated glyoxal and the sulfate ion [C-OH-O=S] (Zhang et al., 2004). Ip et al. observed that in $\mathrm{Na}_{2} \mathrm{SO}_{4}$ solutions glyoxal uptake was enhanced as the concentration of $\mathrm{Na}_{2} \mathrm{SO}_{4}$ increases; [C-OH$\mathrm{O}=\mathrm{S}]$ is comparable to the water-sulfate interaction $[\mathrm{HOH}-$ $\mathrm{O}=\mathrm{S}]$ and is consistent with the similar bond distances of $1.7 \AA$ for [C-OH-O=S] (Zhang et al., 2004) and $1.9 \AA$ for $[\mathrm{HOH}-\mathrm{O}=\mathrm{S}]$ (Schweighofer et al., 1997).

\subsection{Reversibility of oligomers formed by acid catalyzed pathways}

It is important to understand whether oligomer formation is reversible or irreversible in order to determine how SOA yields are affected. Kroll et al. (2005) and Galloway et al. (2009) report that glyoxal oligomers formed through acid catalyzed pathways are reversible. For example, Galloway et al. (2009) observed that glyoxal evaporated from smog chamber SOA when the chamber was diluted with clean air. The SOA in this experiment was formed in the presence of glyoxal with ammonium sulfate seed particles in the dark. In reporting their findings in the form of a reactive uptake coefficient, Liggio et al. (2005a) imply that glyoxal oligomers formed in dark (radical-free) experiments are irreversible, but they did not test this assumption.

It is reasonable to expect that the partitioning of glyoxal between gas and particle (or aqueous) phases is reversible. Hydration of glyoxal is reversible. The reaction between dehydrated and hydrated glyoxals to form hemiacetals is reversible. Many chamber studies suggest that acid-catalyzed hemiacetal formation is a reversible process. For example, the acid catalyzed formation of cyclic hemiacetals from 1,4hydroxycarbonyls is reversible (Martin et al., 2005; Holt et al., 2005; Atkinson et al., 2008; Lim and Ziemann 2009b). Therefore, we expect that this type of oligomer to be reversibly formed.

If the process is reversible, can we expect that glyoxal oligomers remaining in the particle phase after water evaporation will evaporate completely in clean (glyoxal-free) air? While Hastings et al. (2005) found no significant evaporation 
of dehydrated glyoxal while drying water solutions, ammonium might increase oligomer evaporation by catalyzing oligomerization and de-oligomerization in atmospheric particles. Galloway et al. (2009) observed the evaporation of glyoxal from glyoxal SOA formed in the dark on ammonium sulfate seed particles after $\sim 9 \mathrm{~h}$ of exposure to clean air. Although quantitative data on the behavior of glyoxal oligomers formed via hemiacetal formation/aldol condensation as a function of time and with dilution would be helpful, Schwier et al. (2010) also observed no reversible process of glyoxal oligomers upon dilution over several hours. The data to date suggest this process is so slow that it is not likely to be an important sink for glyoxal in the atmosphere. Moreover, the process seems to be only partially reversible. According to Loeffler et al. (2006), there is a solid-to-liquid phase transition factor for dried oligomers to reduce dissociation, so glyoxal evaporation is curtailed. When water droplet evaporates, oligomers form by acid-catalyzed reactions between aldehyde groups in the dehydrated glyoxals and $\mathrm{OH}$ groups in the dihydrated glyoxals. The formation of oligomers indicates the rate of oligomer formation is faster than the rate of glyoxal evaporation. After complete water evaporation, dried oligomers remain mostly in the particle phase because dissociation (or hydrolysis) is minimized: therefore, glyoxal evaporation is curtailed (Loeffler et al., 2006). In summary, thermodynamically, glyoxal oligomers formed through acid catalyzed pathways are reversible; however, kinetically these glyoxal oligomers appear to be relatively stable.

\section{Radical chemistry}

Low volatility products including oligomers from $\mathrm{OH}$ radical oxidation and/or photolysis of methylglyoxal, pyruvic acid, phenolic compounds, and glycolaldehyde have been documented (Altieri et al., 2008; Guzman et al., 2006; Carlton et al., 2006; Altieri et al., 2006; Sun et al., 2010; Perri et al., 2009). Product formation from the $\mathrm{OH}$ radical oxidation of glyoxal was investigated in bulk experiments by Carlton et al. (2007) and later by Tan et al. (2009). Glyoxal could undergo other reactions (e.g., acid/base catalyzed reactions) as well as $\mathrm{OH}$-radical reactions in aerosol water, where aqueous chemistry would be much more complicated. Previously, Tan et al. (2009) observed: (1) the major product was oxalic acid at cloud-relevant concentrations; (2) the real-time formation of oxalic acid and total organic carbon was well predicted by the Lim et al. (2005) aqueous chemistry model (Lim model) when experiments were conducted at cloud-relevant concentrations $(30 \mu \mathrm{M})$; (3) at higher concentrations $(3000 \mu \mathrm{M})$, larger organic acids and oligomers formed as well; (4) with increasing concentration, measurements increasingly deviated from the Lim model predictions. On the basis of these findings Tan et al. (2009) concluded that at aerosol-relevant concentrations $(\sim 3 \mathrm{M})$, the production of larger organic acids and oligomers from $\mathrm{OH}$ chemistry would be substantial. Elucidation of the underlying radical chemistry is the focus of the following sections.

\subsection{Reversibility of oligomers formed by radical reactions}

In the case of aqueous photooxidation (e.g., aqueous-phase reactions of glyoxal with $\mathrm{OH}$ radical) product formation is clearly irreversible.

\subsection{Radical reaction mechanism}

Based on the literature (Carter et al., 1979; Buxton et al., 1988, 1997; Stefan and Bolton, 1998, 1999; Carlton et al., 2007; Tan et al., 2009) we propose the following mechanism for the aqueous-phase reaction of glyoxal with $\mathrm{OH}$ radicals (Fig. 2). After uptake from the gas-phase, dissolved glyoxal in the aqueous phase undergoes hydration. H-atom abstraction occurs by $\mathrm{OH}$ radical reaction and forms a peroxy radical after $\mathrm{O}_{2}$ reaction with $\left[R^{*}{ }_{1}\right]$. The peroxy radical either decomposes to form glyoxylic acid [1] or reacts with another peroxy radical to form an alkoxy radical, which eventually decomposes to formic acid [2] and hydrated carbon dioxide [4]. Glyoxylic acid [1] similarly reacts with an $\mathrm{OH}$ radical to form oxalic acid [3] or carbon dioxide [4]. In the reaction of oxalic acid with $\mathrm{OH}$ radicals $\mathrm{H}$-atom abstraction occurs by breaking an $\mathrm{O}-\mathrm{H}$ bond; this tends to be $\sim 10-100$ times slower than breaking a $\mathrm{C}-\mathrm{H}$ bond according to the estimation method of Monod et al. (2005, 2008). Thus, the final product, carbon dioxide [4] forms slowly.

In addition to glyoxylic acid and oxalic acid, larger organic acids with a higher carbon number than the precursor $\left(>\mathrm{C}_{2}\right)$ and oligomers are formed in $3000 \mu \mathrm{M}$ glyoxal experiments. We use the experimental data below to argue that these higher carbon number products are not formed through acid catalysis, but through "radical-radical" reactions. We expect this radical-radical chemistry to be much more important in wet aerosols where concentrations are $\sim 1-10 \mathrm{M}$ than at the much lower concentrations in cloud/fog water and in the experiments of Tan et al. (2009). The combination of two radical species formed by $\mathrm{H}$-atom abstraction, followed by dehydration, forms a dimer (e.g., $R^{*}{ }_{1}+R^{*}{ }_{1}$ reaction in Fig. 2). The dimer, then, reacts with an $\mathrm{OH}$ radical again to form a trimer, and so on. Experimental evidence for radicalradical reactions is found in the literature (Guzman et al., 2006). Guzman et al. (2006) observed 2,3-dimethyltartaric acid $\left(\mathrm{C}_{6}\right)$ and 2-(3-oxobutan-2-yloxy)-2-hydroxypropanoic acid $\left(\mathrm{C}_{7}\right)$ formed by photolysis of aqueous pyruvic acid $\left(\mathrm{C}_{3}\right)$ via radical-radical reactions in a reactor continuously purged with 1 atm of $\mathrm{O}_{2}$. Figure 3a illustrates 2,3-dimethyltartaric acid formation via radical-radical reactions.

According to the reaction mechanism (Fig. 2), radicalradical reactions always compete with $\mathrm{O}_{2}$ reactions. The formation of a $\mathrm{C}_{4}$ dimer from two $\mathrm{C}_{2}$ radicals competes with the formation of peroxy radicals via $\mathrm{C}_{2}$ radical- $\mathrm{O}_{2}$ reaction. In 
A

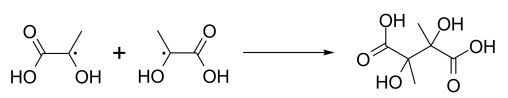

B

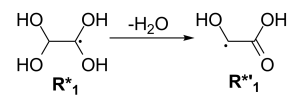

C
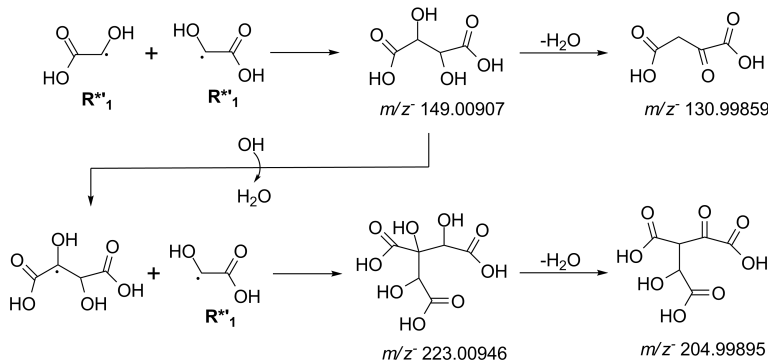

D

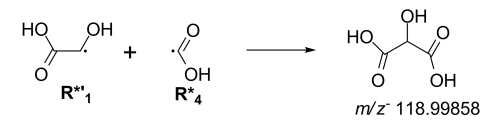

$$
\begin{array}{cc}
\mathrm{O} & \mathrm{OH} \\
m / z^{-} & 118.99858
\end{array}
$$

E
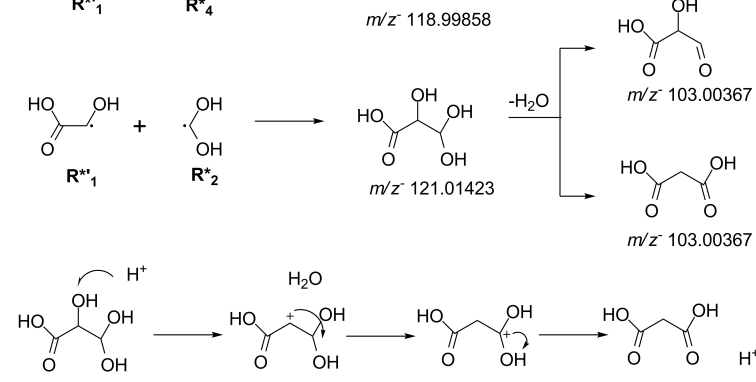

$\mathrm{OH}^{\mathrm{OH}}$

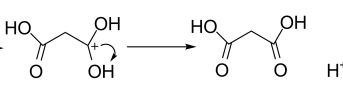

Fig. 3. (A) Formation of 2,3-dimethyltartaric acid via radicalradical reactions (Guzmann et al., 2006). (B) Dehydration of the glyoxal radical (Burchill and Perron, 1971). (C) Formation of tartaric acid $\left(\mathrm{m} / \mathrm{z}^{-} 149\right)$ via radical-radical reactions followed by dehydration. (D) Formation of tartronic acid $\left(\mathrm{m} / \mathrm{z}^{-} 119\right)$ vial radicalradical reactions. (E) Formation via radical-radical reactions followed by dehydration. (F) Proposed acid-catalyzed dehydration for the formation of malonic acid.

order for the radical-radical reactions to compete favorably with $\mathrm{O}_{2}$ reactions, the following conditions have to be met. First, the concentrations of the precursor, glyoxal, should be high (thus, the concentration of the radical species $\left(R^{*}{ }_{1}\right)$ should be also high) relative to the dissolved $\mathrm{O}_{2}$ concentration $(\sim 0.3 \mathrm{mM})$. The experimental results of Tan et al. (2009) suggest that the glyoxal concentration must be at least $\sim \mathrm{mM}$ to observe radical-radical products. Second, the rate constant for radical-radical reactions must be comparable to that for the $\mathrm{O}_{2}$ reactions. $\mathrm{O}_{2}$ reactions are fast. Buxton et al. (1997) reports a rate constant of $\sim 1 \times 10^{9} \mathrm{M}^{-1} \mathrm{~s}^{-1}$. However, in a study of photoinduced oligomerization of aqueous pyruvic acid $(0.1 \mathrm{M})$ Guzman et al. (2006) found that $\mathrm{O}_{2}$ reactions did not efficiently inhibit the radical-radical reactions and they estimated that the rate of the $\mathrm{O}_{2}$ reactions was 1000 times smaller $\left(\sim 1 \times 10^{6} \mathrm{M}^{-1} \mathrm{~s}^{-1}\right)$ than previously reported. They propose that the lower rate is likely due to radical stabilization via inter- and intramolecular hydro- gen bonding; however, the reason is not well understood. Radical-radical reaction rates are considered to be diffusion controlled (Guzman et al., 2006) with a suggested value of $\sim 2 \times 10^{9} \mathrm{M}^{-1} \mathrm{~s}^{-1}$ for the combination of two pyruvic radical species, $\left[\mathrm{H}_{3} \mathrm{C}-\mathrm{C}^{*}(\mathrm{OH})-\mathrm{C}(\mathrm{O}) \mathrm{OH}\right]$. This is consistent with the value of $\sim 1 \times 10^{9} \mathrm{M}^{-1} \mathrm{~s}^{-1}$ for the combination of two acetaldehyde radical species, $\left[\mathrm{H}_{2} \mathrm{C}^{*}-\mathrm{CHO}\right]$ (Burchill et al., 1971).

\subsection{Product formation via radical-radical reactions}

Ultra high resolution FTICR-MS, which provides highly accurate mass (elemental composition) with 4-6 decimal places, provides additional evidence for the proposed radical mechanism. Figure 4 shows the FTICR mass spectrum 30 min into the reaction of $3000 \mu \mathrm{M}$ glyoxal with $\mathrm{OH}$ radicals. The spectrum is obtained in negative mode, which captures carboxylic acids through electrospray ionization of $\mathrm{H}^{+}$, so the mass to charge ratio $\left(\mathrm{m} / \mathrm{z}^{-}\right)$indicated in the spectrum is one unit less than the molecular weight. The major peaks are $m / z^{-1} 18.99858,149.00907$, and 223.00946. It is important to note that these are not formed through acid catalysis because they do not appear in control experiments conducted without $\mathrm{OH}$ radicals (Fig. 5). Proposed formations via radical-radical reactions are illustrated in Fig. 3. According to the reaction mechanism in Fig. 2, we expect $R^{*}{ }_{1}$ to be a pronounced radical compound because it is the first radical product formed immediately after the $\mathrm{H}$-atom abstraction from the glyoxal-OH reaction. Under irradiated conditions, dehydration occurs to $R^{*}{ }_{1}$ forming $R^{* \prime}{ }_{1}$ (Fig. 3b) (Burchill and Perron, 1971). The $\mathrm{m} / \mathrm{z}^{-} 149.00907$ $\left(\mathrm{C}_{4} \mathrm{H}_{6} \mathrm{O}_{6}\right.$, tartaric acid) can be formed from combining two $R^{* \prime}{ }_{1} \mathrm{~s}$ (Fig. 3c). $\mathrm{m} / \mathrm{z}^{-} 130.99859$ could form by dehydration of $m / z^{-} 149.00907$ (Fig. 3c). $m / z^{-} 223.00946\left(\mathrm{C}_{6} \mathrm{H}_{7} \mathrm{O}_{9}\right)$ can form from the H-atom abstracted $\mathrm{m} / \mathrm{z}^{-} 149.00907$ and the dehydrated $R^{*}{ }_{1}\left(R^{* \prime}{ }_{1}\right)$. Similarly, $\mathrm{m} / z^{-} 204.99895$ is the dehydrated form of $m / z^{-223.00946 ~(F i g . ~ 3 c) . ~ A n ~ i m-~}$ portant observation is that the mass spectra contain a series of peaks with $\mathrm{m} / \mathrm{z}^{-}$difference of 74.00036 (Table 1). As shown for $\mathrm{m} / \mathrm{z}^{-} 149.00907$ and 223.00946 in Fig. 3c, the $\mathrm{m} / \mathrm{z}^{-} 74.00036$ increase can be explained by the reaction with $R^{* \prime}{ }_{1} . m / z^{-} 118.99858\left(\mathrm{C}_{3} \mathrm{H}_{4} \mathrm{O}_{5}\right)$ can be formed from $R^{* \prime}{ }_{1}$ and $R_{4}^{*}$ (Fig. 3d). Similarly, $m / z^{-} 121.0142\left(\mathrm{C}_{3} \mathrm{H}_{6} \mathrm{O}_{5}\right)$ can be formed from $R^{* \prime}{ }_{1}$ and $R_{3}^{*}$ (Fig. 3e).

FTICR-MS analysis suggests that the contribution of radical-radical reactions to oligomer formation from $\mathrm{OH}$ oxidation of aqueous glyoxal is profound. The formation of 25 out of the $30 \mathrm{~m} / \mathrm{z}^{-}$absorbances with signal intensities over 10000 in the range from $\mathrm{m} / \mathrm{z}^{-} 100$ to 500 can be explained by radical-radical reactions. The presence of a series of peaks increasing by $\mathrm{m} / \mathrm{z}^{-} 74$ (Table 1) also supports a radical-radical mechanism. Since $R^{* \prime}{ }_{1}$ is the first radical product of the glyoxal-OH reactions, it should be an abundant radical source for radical-radical reactions. 
Table 1. A series of oligomeric products increasing by $\mathrm{m} / \mathrm{z}^{-} 74$ formed from the radical-reaction of $\mathrm{H}$-atom abstracted parent radical products with the dehydrated glyoxal radical $\left(R^{* \prime} 1\right)$.

\begin{tabular}{lllll}
\hline Parent Fomula $^{\mathrm{a}}$ & $\Delta m / z^{-\mathrm{b}}$ (Ion Abundance) & Oligomer Formula $^{\mathrm{c}}$ & $m / z^{-}$(Ion Abundance) & $\Delta m / z^{-\mathrm{d}}$ \\
\hline $\mathrm{C}_{4} \mathrm{H}_{6} \mathrm{O}_{6}$ & $149.00907(7074634.5)$ & $\mathrm{C}_{6} \mathrm{H}_{8} \mathrm{O}_{9}$ & $223.00946(1613206.1)$ & 74.00036 \\
$\mathrm{C}_{3} \mathrm{H}_{4} \mathrm{O}_{6}$ & $134.99347(490871.2)$ & $\mathrm{C}_{5} \mathrm{H}_{6} \mathrm{O}_{9}$ & $208.99387(246661.4)$ & 74.00040 \\
& & $\mathrm{C}_{7} \mathrm{H}_{8} \mathrm{O}_{12}$ & $282.99417(475.2)$ & 74.00030 \\
$\mathrm{C}_{4} \mathrm{H}_{6} \mathrm{O}_{5}$ & $133.01422(475762.8)$ & $\mathrm{C}_{6} \mathrm{H}_{8} \mathrm{O}_{8}$ & $207.01461(230577.6)$ & 74.00039 \\
& & $\mathrm{C}_{8} \mathrm{H}_{10} \mathrm{O}_{11}$ & $281.01495(47589.1)$ & 74.00034 \\
& $\mathrm{C}_{10} \mathrm{H}_{12} \mathrm{O}_{14}$ & $355.01529(17054.8)$ & 74.00034 \\
& & $\mathrm{C}_{12} \mathrm{H}_{14} \mathrm{O}_{17}$ & $429.01569(24187.4)$ & 74.00040 \\
$\mathrm{C}_{8} \mathrm{H}_{12} \mathrm{O}_{11}$ & $283.03061(21427.9)$ & $\mathrm{C}_{10} \mathrm{H}_{14} \mathrm{O}_{14}$ & $357.03092(18137.9)$ & 74.00031 \\
& & $\mathrm{C}_{12} \mathrm{H}_{16} \mathrm{O}_{17}$ & $431.03130(28850.3)$ & 74.00038 \\
$\mathrm{C}_{6} \mathrm{H}_{8} \mathrm{O}_{6}$ & $175.02480(52703.2)$ & $\mathrm{C}_{8} \mathrm{H}_{10} \mathrm{O}_{9}$ & $249.02520(83480.7)$ & 74.00040 \\
$\mathrm{C}_{5} \mathrm{H}_{6} \mathrm{O}_{7}$ & $177.00405(98101.2)$ & $\mathrm{C}_{7} \mathrm{H}_{8} \mathrm{O}_{10}$ & $251.00444(106218.2)$ & 74.00039 \\
$\mathrm{C}_{8} \mathrm{H}_{12} \mathrm{O}_{12}$ & $299.02529(239182.1)$ & $\mathrm{C}_{10} \mathrm{H}_{14} \mathrm{O}_{15}$ & $373.02577(11630.2)$ & 74.00048 \\
& & $\mathrm{C}_{12} \mathrm{H}_{16} \mathrm{O}_{18}$ & $447.02590(136621.9)$ & 74.00013 \\
\hline
\end{tabular}

a Molecular formula before $\mathrm{H}$-atom abstraction by $\mathrm{OH}$ radicals.

b FTICR-MS mass in negative ionization mode.

c Oligomer refers to dimer, trimer and higher compound.

${ }^{\mathrm{d}}$ Difference of $\mathrm{m} / \mathrm{z}^{-}$values between a dimer and a parent product or between a higher molecular weight oligomer and a lower molecular weight oligomer.

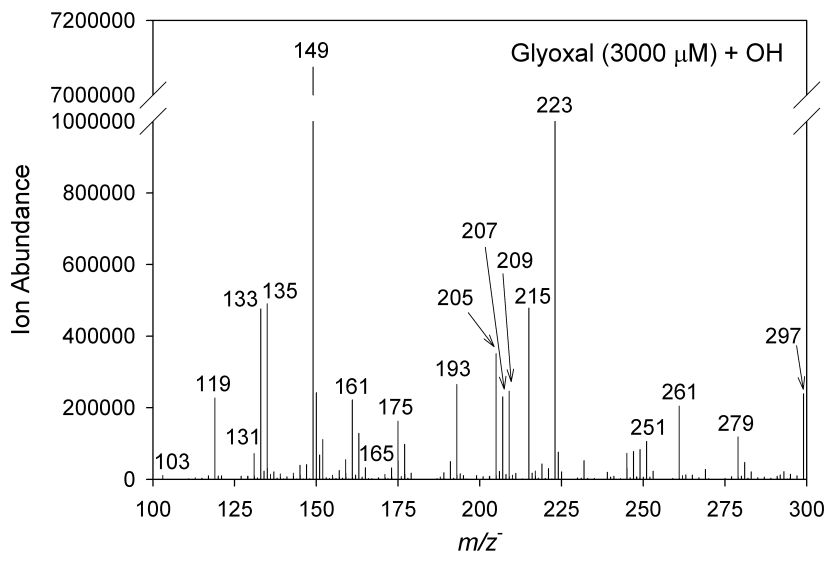

Fig. 4. FTICR-mass spectrum of the products formed from the 30 min-reaction of glyoxal $(3000 \mu \mathrm{M})$ with $\mathrm{OH}$ radicals, detected in negative ionization mode.

Nonetheless, it is worth noting that some products can be explained by non-radical acid catalyzed pathways. The peak at $m / z^{-} 165.00405\left(\mathrm{C}_{4} \mathrm{H}_{6} \mathrm{O}_{7}\right)$ appears in the negative ionization mode sample spectrum (Fig. 4). This peak could form by radical-radical reactions or acid catalysis. However, if the product were formed through radical-radical reactions, it is expected to be a diacid (Fig. 6a), which will not be detected in the positive ionization mode (aldehydes and alcohols are expected to be seen in positive ionization mode). The presence of a peak at $\mathrm{m} / \mathrm{z}^{+} 189$ (unit mass) in ESI-MS positive ionization mode sample spectrum is consistent with forma-

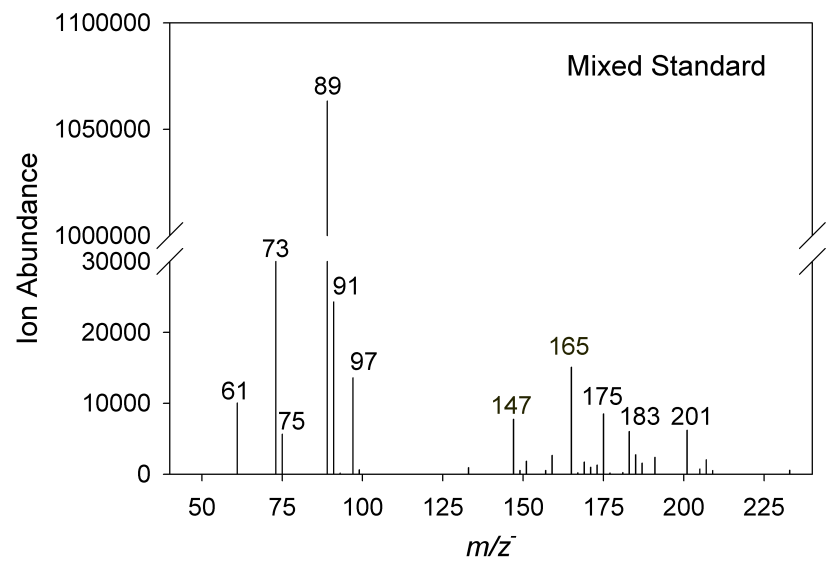

Fig. 5. Negative mode ESI-MS of a mixed standard that contains glyoxal, glycolic acid, glyoxylic acid, oxalic acid, and sulfuric acid. The mass spectrum is in fact a net spectrum obtained by subtracting mixed standard with concentrations of $25 \mu \mathrm{M}$ for all elements from that with $200 \mu \mathrm{M}$

tion through acid catalysis (Fig. 6b). $\mathrm{m} / \mathrm{z}^{-} 165$ was also seen in the mixed standard (Fig. 5); this peak could result from acid catalysis but we cannot rule out the possibility that this product formed during electrospray ionization.

In order to confirm the dominance of the radical-radical reactions, the contribution of acid catalysis was investigated by examining the spectra of mixed standards. Figure 5 is an ESI-mass spectrum in negative ionization mode for the mixed standard which contains glyoxal, glyoxalic acid, 
(A)

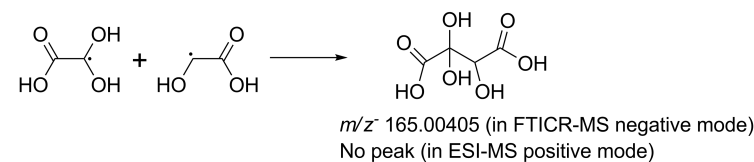

(B)

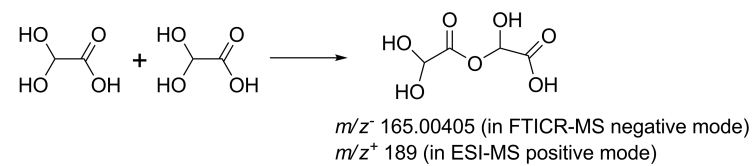

Fig. 6. MW 166 organic product formed through a radical-radical reaction (A) or acid catalysis (B).

glycolic acid, oxalic acid, and sulfuric acid. Acid catalyzed (non-radical) products can form in this mixture; and products could form as a result of electrospray ionization, but radical-radical reactions are not expected. In order to remove contaminant peaks, the spectrum for a mixed standard with concentrations of $25 \mu \mathrm{M}$ for all elements was subtracted from that with $200 \mu \mathrm{M} . \mathrm{m} / z^{-} 73,75,89$, and 97 represent glyoxalic acid, glycolic acid and oxalic acid, and sulfuric acid, respectively. $m / z^{-} 91$ represents the hydrated form of glyoxalic acid. There are also contaminants present in the mixed standard; for example, $\mathrm{m} / \mathrm{z}^{-} 61$ is likely to be carbonic acid. Since there are no $\mathrm{OH}$ reactions involved and the solution is acidic ( $\sim \mathrm{pH} 4)$, some of the peaks over $\mathrm{m} / \mathrm{z}^{-} 100$ could form through acid catalysis. The peaks at $m / z^{-} 147$ and 165 could be formed through acid catalyzed pathways $\left(\mathrm{m} / \mathrm{z}^{-} 175,183\right.$ and 201 are unidentified peaks). There are two possible pathways for $m / z^{-} 165$ : reactions of glyoxal and oxalic acid, or reactions of two hydrated glyoxylic acids (Fig. 7a). In both cases, dimers could be formed through condensation reactions (esterification) since one $\mathrm{OH}$ group in dihydrated glyoxal for glyoxal-oxalic acid reactions (or hydrated glyoxylic acid for two glyoxalic acid reactions) can attack the carbon in a carbonyl group and form an ester while losing water. $m / z^{-} 147$ could be the dehydrated product of $\mathrm{m} / \mathrm{z}^{-} 165$ formed by the reaction of glyoxal with oxalic acid, or formed by the reaction of glycolic acid with oxalic acid (Fig. 7b). Alternatively, these products could be formed as a result of the electrospray process (Altieri et al., 2008). In either case, the mass spectrum (Fig. 5) of the mixed standard does not have common peaks with that for $\mathrm{OH}$ radical reactions (Fig. 4). Therefore, neither non-radical acid catalyzed pathways nor the electrospray itself can explain the glyoxal $+\mathrm{OH}$ high molecular weight products. Clearly, acid catalysis is only a minor contributor to the products formed from glyoxal when $\mathrm{OH}$ radical is present.

\subsection{Kinetic modeling of radical reactions}

The results of the new model were compared with the previously published model of Lim et al. (2005). The Lim 2005 model is a photochemical box model to investigate SOA for- mation through the gas- and aqueous-phase photochemistry of isoprene. All the photochemical reactions in the model are represented by final products with branching ratios (stoichiometric coefficients) without detailed intermediate radical reactions (e.g., formation of peroxy radicals).

The new model performs better for $3000 \mu \mathrm{M}$ glyoxal $+\mathrm{OH}$ radical experiments than the Lim 2005 model. Both models agree well with oxalic acid measurements at $30 \mu \mathrm{M}$ (Fig. 8a), which is considered a cloud-relevant concentration of glyoxal. However, for $3000 \mu \mathrm{M}$ glyoxal $+\mathrm{OH}$ experiments, the previous model (Lim et al., 2005) overestimated the peak oxalic concentration; modeled oxalic acid appeared earlier and decayed faster than the measurements of oxalic acid (Fig. 8b). The main reason for the disagreement between the model and measurement is that the Lim 2005 model does not include the formation of the larger acids, which are observed in higher concentration experiments (Tan et al., 2009). By including radical-radical reactions, the new model has brought the timing, shape, and magnitude of the oxalic acid peak in closer agreement with measurements (Fig. 8b). Although there is still some deviation early $(<1 \mathrm{~h})$ in the reaction, it is not outside the uncertainty in $\mathrm{OH}$ radical concentrations introduced by the scattering interference of products to $\mathrm{OH}$ radical generation through photolysis of $\mathrm{H}_{2} \mathrm{O}_{2}$ (Adjustment of the photolysis rate of hydrogen peroxide from $1.1 \times 10^{-4} \mathrm{~s}^{-1}$ to $8.0 \times 10^{-5} \mathrm{~s}^{-1}$ shifts the simulated peak of oxalic acid to the measurement peak). The rate constant of $1.1 \times 10^{-4} \mathrm{~s}^{-1}$ for $\mathrm{OH}$ radical formation is measured in the absence of organic compounds in the solution; the mixed standard plus UV control experiment suggests this is reasonable (Tan et al., 2009).

The new model simulation of tartaric acid (Fig. 3c) and the IC measurements of tartaric plus malonic acids are plotted in Fig. 8c. The IC measurements are the superposition of tartaric acid and malonic acid. They have the same retention time and therefore are indistinguishable in the IC analyses. However, FTICR-MS and ESI-MS analyses (Fig. S2) indicate that tartaric acid $\left(m / z^{-} 149.00907 ; \mathrm{C}_{4} \mathrm{H}_{6} \mathrm{O}_{6}\right)$ is responsible for the large IC peak at $\sim 25 \mathrm{~min}$. of reaction time and malonic acid $\left(103.00367 ; \mathrm{C}_{3} \mathrm{H}_{4} \mathrm{O}_{4}\right)$ is responsible for the shoulder at $\sim 125 \mathrm{~min}$. in Fig. $8 \mathrm{c}$. By using the rate constants, $1.3 \times 10^{9} \mathrm{M}^{-1} \mathrm{~s}^{-1}$ and $1.0 \times 10^{6} \mathrm{M}^{-1} \mathrm{~s}^{-1}$, for the radicalradical reactions and the radical- $\mathrm{O}_{2}$ reactions, respectively, the tartaric acid concentration dynamics are well captured.

The slow formation of malonic acid, $\mathrm{m} / \mathrm{z}^{-} 103$ (103.00367 in the FTICR-MS), relative to tartaric acid is consistent with a malonic acid formation pathway involving acid catalysis. We propose that malonic acid can be formed through radical-radical reaction followed by acid-catalyzed dehydration (Fig. 3f). This was included in the model. The simulated malonic acid agrees with $\mathrm{m} / \mathrm{z}^{-} 103$ when a dehydration rate constant of $1 \times 10^{-3} \mathrm{~s}^{-1}$ and the upper limit of the hydration rate constant $\left(1 \times 10^{-8} \mathrm{~s}^{-1}\right)$ for acid catalysis are used (Fig. S3). Details are discussed in the Supplement. To the best of our knowledge, kinetic data for acid catalysis are 
(A)
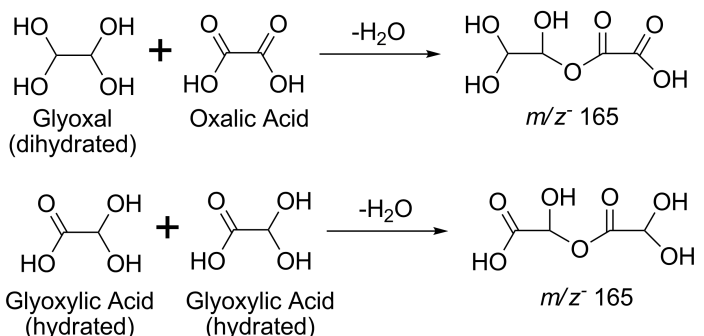

(B)
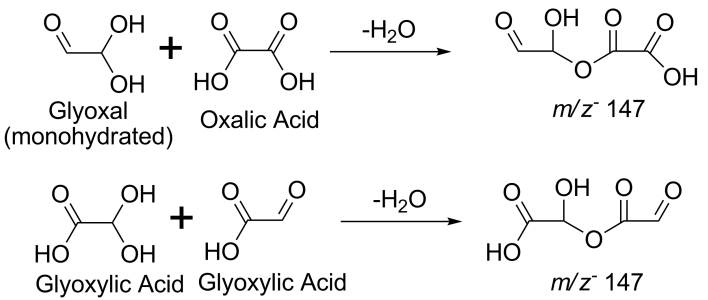
(hydrated)

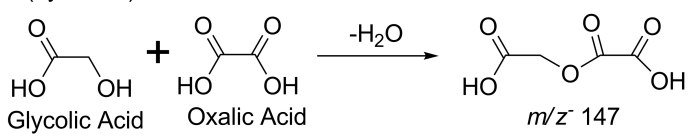

Fig. 7. Proposed acid-catalyzed esterification explaining $\mathrm{m} / \mathrm{z}^{-} 165$ and 147 dimers found in the standard mixture.

largely unavailable. However, it is worth noting that Lim and Ziemann (2009b) estimated a dehydration rate $\left(1 \times 10^{-3} \mathrm{~s}^{-1}\right)$ for the acid-catalyzed conversion of cyclic hemiacetals to dihydrofurans in the aerosol phase during the gas-phase chamber reactions of $\mathrm{C}_{13}-\mathrm{C}_{17}$ linear alkanes $+\mathrm{OH}$ radical at high $\mathrm{NO}_{\mathrm{x}}$. This dehydration rate was independent of the number of carbons in the cyclic hemiacetal because acid catalysis only occurs in two neighboring carbons. In the proposed malonic acid formation mechanism, acid catalysis also occurs in the 1,2 carbon positions (Fig. 3f). So, it might not be a coincidence that the dehydration rate is identical. The hydration rate constant for the decay of malonic acid is five orders of magnitude lower than the dehydration rate constant. Since acid catalysis occurs in the aqueous phase, one might expect the hydration rate to be important. However, the structure of malonic acid is not conductive to water uptake because the proton transition from a terminal carbon to the middle is not likely to be favorable (the reverse reaction of Fig. 3c). Therefore, the negligible hydration rate is reasonable, and the formation of malonic acid is practically irreversible. The decay of malonic acid after $\sim 50 \mathrm{~min}$ of the reaction time (Fig. S3) is due to further $\mathrm{OH}$ radical reactions.

Our new model shows that increasing the initial glyoxal concentration enhances oligomer formation $\left(C_{4}\right.$ and $C_{3}$ dimers) via radical-radical reactions while oxalic acid formation decreases. Figure 9 illustrates the predicted mass-based yields of oxalic acid and oligomers (at their maximum concentrations; in the left y axis) with increasing initial glyoxal concentration for glyoxal $+\mathrm{OH}$ reactions. (Note that product formation continues after glyoxal is fully depleted.) The
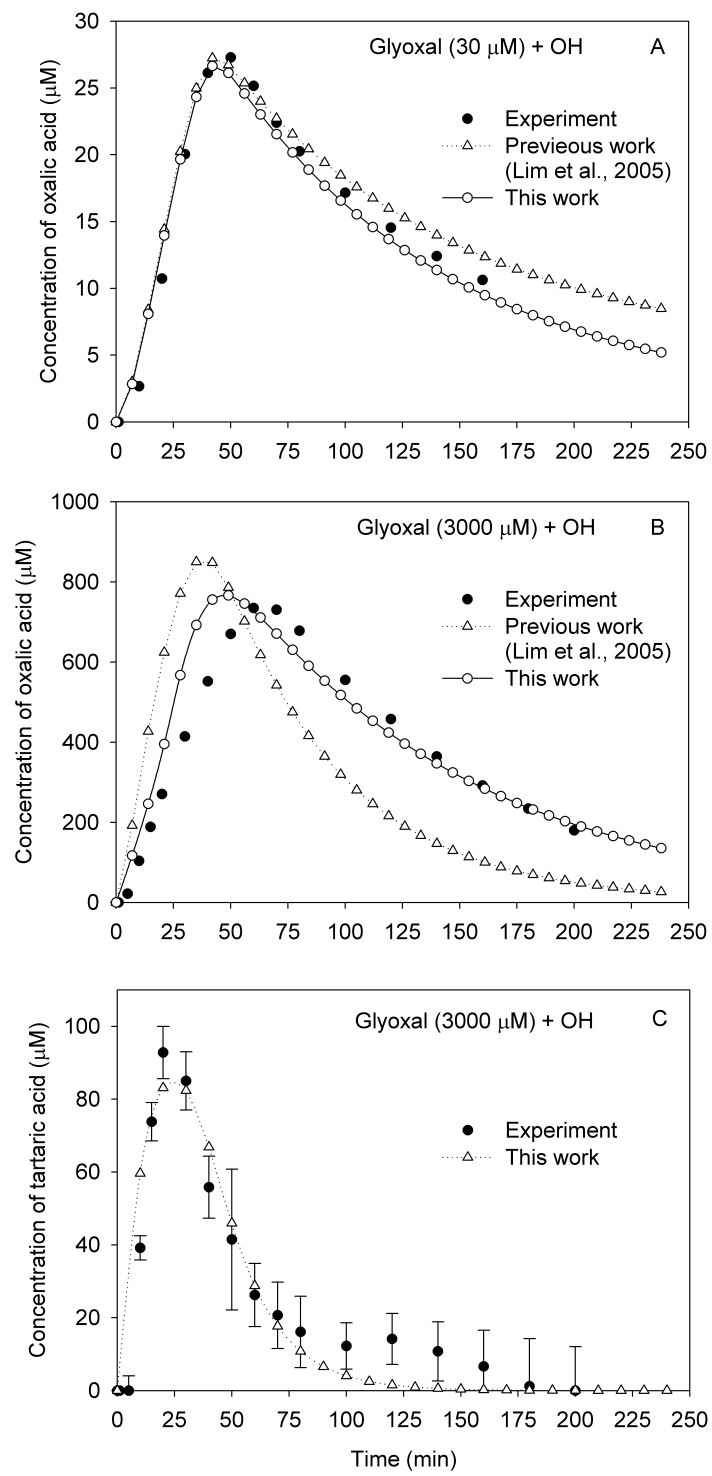

Fig. 8. IC measurements of oxalic acid formed from OH-radical reactions of glyoxal at $30 \mu \mathrm{M}(\mathbf{A})$ and $3000 \mu \mathrm{M}(\mathbf{B})$, and model simulations from the previous work (Lim et al., 2005) and this work. (C) IC measurements (tartaric acid + malonic acid) and the model simulation for tartaric acid.

Fig. 9a simulation is designed to replicate the laboratory experiments. In this case, $\mathrm{OH}$ radical is generated in the model by $\mathrm{H}_{2} \mathrm{O}_{2}$ photolysis, and the initial concentration of $\mathrm{H}_{2} \mathrm{O}_{2}$ is set to be 5 times the initial glyoxal concentration. Note that, in addition to forming $\mathrm{OH}$ radical, $\mathrm{H}_{2} \mathrm{O}_{2}$ reacts with glyoxylic acid reducing yields. The Fig. $9 \mathrm{~b}$ simulation is designed to more closely replicate atmospheric waters, where the gas phase is the main source of $\mathrm{OH}$ radicals: $[\mathrm{OH}]_{\mathrm{aq}}$ is constant and initial $\left[\mathrm{H}_{2} \mathrm{O}_{2}\right]$ is zero. At cloud-relevant concentrations $\left(10^{-5}-10^{-4} \mathrm{M}\right.$ of initial glyoxal concentrations) the predicted yield of oxalic acid is $\sim 140 \%$. The predicted 
yields of oxalic acid in Fig. 9a are consistent with experimental yields (Tan et al., 2009). At $10^{-2} \mathrm{M}$ in Fig. 9a, the sum of the yields is only $37 \%$ because the reaction of $\mathrm{H}_{2} \mathrm{O}_{2}+$ glyoxylic acid to form formic acid (Reaction (41) in Table S1) competes with oxalic acid and oligomer formation (Tan et al., 2009). The yield is considerably higher when initial $\mathrm{H}_{2} \mathrm{O}_{2}$ is set to zero (Fig. 9b). At $10^{-2} \mathrm{M}$ the yield of oligomers exceeds that of oxalic acid. At aerosol-relevant concentrations (1-10 M), the yield of oligomers is over $80 \%$ while oxalic acid formation is negligible. Note that it is preferable to use the chemistry, rather than the yields, in chemical transport models. The model predictions illustrated in Fig. 9 suggest that glyoxal SOA formed in cloud water is predominantly oxalic acid and glyoxal SOA formed in aerosol water is predominantly oligomeric. The turnover occurs at $\sim \mathrm{mM}$ of initial glyoxal.

\section{$6.5 \mathrm{O} / \mathrm{C}$ ratio}

Average O/C ratios for products from glyoxal $+\mathrm{OH}$ radical reactions are estimated by using FTICR-MS data for $3000 \mu \mathrm{M}$ glyoxal and ESI-MS data for $30 \mu \mathrm{M}$ glyoxal with results of kinetic modeling (Fig. 9). Major products from $30 \mu \mathrm{M}$ glyoxal $+\mathrm{OH}$ radical reactions are glyoxylic acid and oxalic acid based on 20 min ESI-MS data (Tan et al., 2009). However, model simulations suggest that at $\sim 40 \mathrm{~min}$ glyoxylic acid completely disappears and oxalic acid $(\mathrm{O} / \mathrm{C}=2)$ is the only product afterward. Therefore, average $\mathrm{O} / \mathrm{C}$ ratios of 2 at this cloud-relevant concentration $\left(10^{-5}-10^{-4} \mathrm{M}\right)$ are reasonable (Fig. 9). Average $\mathrm{O} / \mathrm{C}$ ratios for oligomers in the range of $\mathrm{m} / \mathrm{z}^{-}$200-500 (Kiss et al., 2003; Graber and Rudich, 2006; Altieri et al., 2008; Perri et al., 2009) in FTICR-MS data are $1.2(\mathrm{OM} / \mathrm{OC}=2.7)$, similar to $\mathrm{O} / \mathrm{C}$ measured in atmospheric HULIS (Graber and Rudich, 2006; Jimenez et al., 2010). Based on the kinetic modeling above, we expect products like these to dominate in the $\mathrm{OH}$ radical oxidation of glyoxal in wet aerosols; therefore, at 1-10 M the average $\mathrm{O} / \mathrm{C}$ ratios are 1 (Fig. 9). Since both oxalic acid and oligomers are formed at $10^{-3}-10^{-2} \mathrm{M}$, average $\mathrm{O} / \mathrm{C}$ ratios have been weighed by mass-based yields of oxalic acid $(\mathrm{O} / \mathrm{C}=2)$ and oligomers $(\mathrm{O} / \mathrm{C}=1)$. In Fig. 9, O/C decreases from 2 to 1 as initial glyoxal concentrations increase from $10^{-3} \mathrm{M}$ to $10^{-2} \mathrm{M}$.

\section{Conclusions}

Cloud/fog water and aerosol water are important media that allow volatile but highly water soluble organic precursors (e.g., glyoxal in this work) to form low volatility products and SOA through condensed phase reactions. Once glyoxal is formed in the atmosphere through photochemical processes acting on biogenic and anthropogenic emissions, it will dissolve in cloud/fog droplets and wet aerosol. In cloud/fog droplets during daylight hours, glyoxal will re-
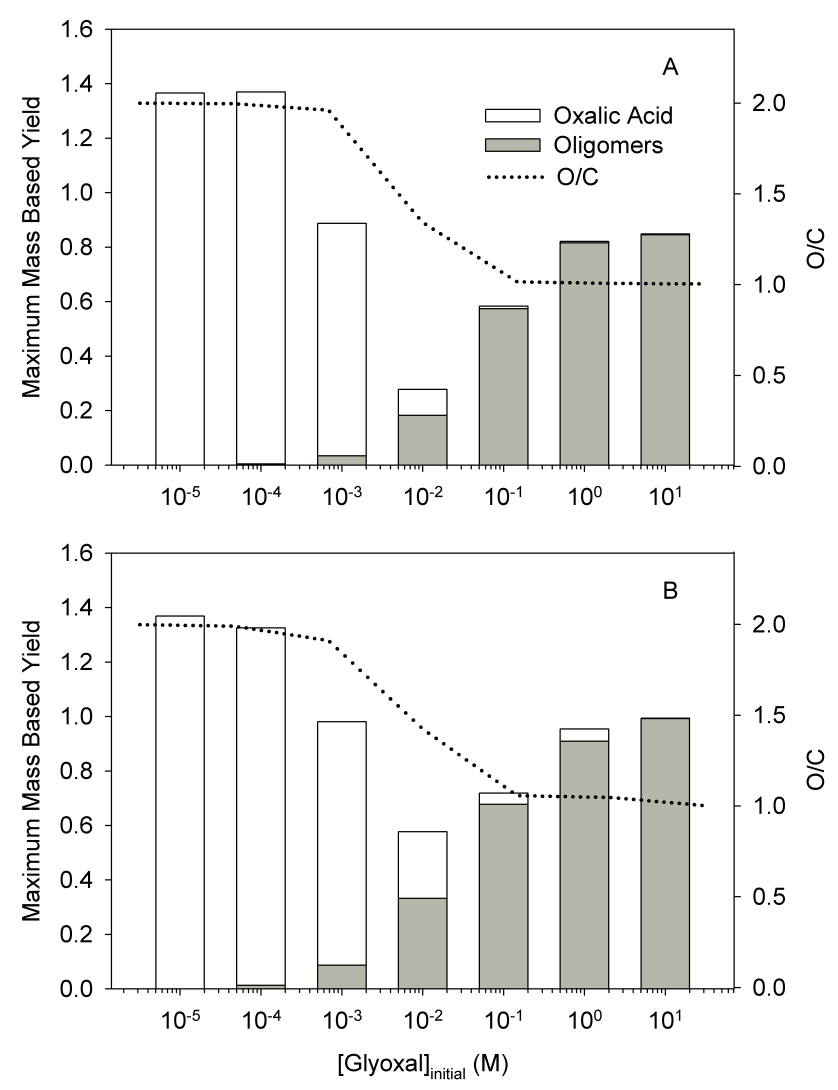

Fig. 9. Predicted maximum mass based yields (in the left y axis) of oxalic acid and oligomers $\left(\mathrm{C}_{3}+\mathrm{C}_{4}\right.$ dimers $)$ with increasing initial concentrations of glyoxal for aqueous-phase reactions with $\mathrm{OH}$ radicals: (A) for lab conditions ( $\mathrm{OH}$ radical is generated by $\mathrm{H}_{2} \mathrm{O}_{2}$ photolysis; $\mathrm{H}_{2} \mathrm{O}_{2}$ also reacts with glyoxylic acid reducing yields; $\left.\left[\mathrm{H}_{2} \mathrm{O}_{2}\right]=5 \times[\text { Glyoxal }]_{\text {initial }}\right)$, and (B) for atmospheric conditions $\left([\mathrm{OH}]_{\mathrm{aq}}\right.$ is constant; $\mathrm{H}_{2} \mathrm{O}_{2}$ is zero). For case $\mathrm{A},[\mathrm{OH}]_{\mathrm{aq}}$ is $(1-10) \mathrm{e}-$ $12 \mathrm{M}$. For case $\mathrm{B},[\mathrm{OH}]_{\mathrm{aq}}$ is $2.8 \mathrm{e}-12 \mathrm{M}$. Simulated $\mathrm{pH}$ is $4.8-1.5$ at low to high [Glyoxal $]_{\text {initial }}$. Similarly, O/C ratios (in the right y axis) with increasing initial glyoxal concentrations: (A) for lab conditions and (B) for atmospheric conditions.

act with $\mathrm{OH}$ radicals irreversibly to form oxalic acid. Unreacted glyoxal will form (reversible) oligomers through acid catalyzed hemiacetal formation during cloud/fog evaporation. In wet aerosols, irreversible reactions with $\mathrm{OH}$ radicals will produce oligomers or HULIS via radical-radical reactions. Additionally, organic compounds could react with other aerosol constituents such as sulfate, ammonium and amides, forming sulfur and nitrogen containing organics (Perri et al., 2010; Noziere et al., 2008). Self oligomerization of glyoxal through acid catalyzed hemiacetal formation/aldol condensation will also occur in wet aerosols.

Importantly, aqueous chemistry can explain the high O/C ratios in the atmosphere and could increase the hygroscopicity of aerosols. Including this chemistry in chemical transport models increases predicted SOA because "aqueous" 
SOA forms from different precursors than SOA formed through gas phase reactions and partitioning to organic matter. This will be particularly true in locations with high humidity, such as the eastern US While glyoxal and methylglyoxal are the most well studied precursors, other small carbon number atmospheric gases with high water solubilities (e.g., carbonyl compounds, alcohols, organic acids, organic peroxides) will undergo similar aqueous processing (Blando and Turpin, 2000).

\section{Supplementary material related to this article is available online at: http://www.atmos-chem-phys.net/10/10521/2010/ acp-10-10521-2010-supplement.pdf.}

Acknowledgements. This research has been supported by a grant from the US Environmental Protection Agency's Science to Achieve Results (STAR) program (Grant R833751), the National Science Foundation (NSF; 0630298), and National Oceanic and Atmospheric Administration (NOAA; NA07OAR4310279). Although the research described in this paper has been funded wholly or in part by the US Environmental Protection Agency's STAR program, it has not been subjected to any EPA review and therefore does not necessarily reflect the views of the Agency, and no official endorsement should be inferred. The authors acknowledge Melissa Soule, Elizabeth Kujawinski, Katye Altieri, Mary Moore, and funding sources of the WHOI FT-MS User's Facility (NSF OCE-0619608 and the Gordon and Betty Moore Foundation).

Edited by: N. M. Donahue

\section{References}

Aiken, A. C., DeCarlo, P. F., Kroll, J. H., Worsnop, D. R., Huffman, J. A., Docherty, K., Ulbrich, I. M., Mohr, C., Kimmel, J. R., Sueper, D., Zhang, Q., Sun, Y., Trimborn, A., Northway, M., Ziemann, P. J., Canagaratna, M. R., Onasch, T. B., Alfarra, R., Prevot, A. S. H., Dommen, J., Duplissy, J., Metzger, A., Baltensperger, U., and Jimenez, J. L.: O/C and OM/OC ratios of primary, secondary, and ambient organic aerosols with high resolution time-of-flight aerosol mass spectrometry, Environ. Sci. Technol., 42, 4478-4485, 2008.

Altieri, K. E., Carlton, A. G., Lim, H. J., Turpin, B. J., and Seitzinger, S.: Evidence for oligomer formation in clouds: Reactions of isoprene oxidation products, Environ. Sci. Technol., 40, 4956-4960, 2006.

Altieri, K., Seitzinger. S. P., Carlton, A. G., Turpin, B. J., Klein, G. C., and Marshall, A. G.: Oligomers formed through in-cloud methylglyoxal reactions: chemical composition, properties, and mechanisms investigated by ultra-high resolution FT-ICR Mass Spectrometry, Atmos. Environ., 42, 1476-1490, 2008.

Arakaki, T. and Faust, B. C.: Sources, sinks, and mechanisms of hydroxyl radical $(\mathrm{OH})$ photoproduction and consumption in authentic acidic continental cloud waters from Whiteface Mountain, New York: The role of the Fe(r) $(r=$ II, III) photochemical cycle, J. Geophys. Res., 103(D3), 3487-3504, 1998.
Atkinson, R.: Atmospheric chemistry of VOCs and $\mathrm{NO}_{\mathrm{x}}$, Atmos. Environ. 34, 2063-2101, 2000.

Atkinson, R., Arey, J., and Aschmann, S. M.: Atmospheric chemistry of alkanes: Review and recent developments, Atmos. Environ., 42, 5859-5871, 2008.

Atkinson, R., Baulch, D. L., Cox, R. A., Crowley, J. N., Hampson, R. F., Hynes, R. G., Jenkin, M. E., Rossi, M. J., Troe, J., and IUPAC Subcommittee: Evaluated kinetic and photochemical data for atmospheric chemistry: Volume II - gas phase reactions of organic species, Atmos. Chem. Phys., 6, 3625-4055, doi:10.5194/acp-6-3625-2006, 2006.

Barsanti, K. C. and Pankow, J. F.: Thermodynamics of the formation of atmospheric organic particulate matter by accretion reactions - 2. Dialdehydes, methylglyoxal and diketones, Atmos. Environ., 39, 6597-6607, 2005.

Blando J. and Turpin, B.: Secondary organic aerosol formation in cloud and fog droplets: a literature evaluation of plausibility, Atmos. Environ., 34, 1623-1632, 2000

Burchill, C. E. and Perron, K. M.: Radiation-induced rearrangement of ethylene glycol in aqueous solution, Canadian J. Chem., 49, 2382-2389, 1971.

Buxton, G. V., Greenstock, C. L., Helman, W. P., and Ross, A. B. Critical review of rate constants of hydrated electrons, hydrogen atoms and hydroxyl radicals $(\mathrm{OH} / \mathrm{O}-)$ in aqueous solution, $\mathrm{J}$. Phys. Chem. Ref. Data, 17, 513-886, 1988.

Buxton, G. V., Malone, T. N., and Salmon, G. A.: Oxidation of glyoxal initiated by ${ }^{\bullet} \mathrm{OH}$ in oxygenated aqueous solution, J. Chem. Soc. Faraday Trans., 93, 2889-2891, 1997.

Carlton, A. G., Pinder R. W., Bhave, P. V., and Pouliot, G. A.: To what extent can biogenic SOA be controlled? Environ. Sci. Technol., 44(9), 3376-3380, 2010.

Carlton, A. G., Turpin, B. J., Altieri, K., Seitzinger, S., Mathur, R., and Roselle, S.: CMAQ model performance enhanced when incloud secondary organic aerosol is included: Comparisons of organic carbon predictions with measurements, Environ. Sci. Technol., 42, 8798-8802, 2008.

Carlton, A. G., Turpin, B. J., Altieri, K. E., Seitzinger, S., Reff, A., Lim, H. J., and Ervens, B.: Atmospheric oxalic acid and SOA production from glyoxal: results of aqueous photooxidation experiments, Atmos. Environ., 41, 7588-7602, 2007.

Carlton, A. G., Turpin, B. J., Lim, H. J., Altieri, K. E., and Seitzinger, S.: Link between isoprene and secondary organic aerosol (SOA): Pyruvic acid oxidation yields low volatility organic acids in clouds, Geophys. Res. Lett., 33, L06822, doi:10.1029/2005GL025374, 2006.

Carter, W. P. L., Darnall, K. R., Graham, R. A., Winer, A. M., and Pittts, Jr., J.: Reactions of $\mathrm{C}_{2}$ and $\mathrm{C}_{4} \alpha-$ Hydroxy radicals with Oxygen, J. Phys. Chem., 83, 2305-2311, 1979.

Chen, J., Griffin, R. J., Grini, A., and Tulet, P.: Modeling secondary organic aerosol formation through cloud processing of organic compounds, Atmos. Chem. Phys., 7, 5343-5355, doi:10.5194/acp-7-5343-2007, 2007.

de Gouw, J. A., Brock, C. A., Atlas, E. L., Bates, T. S., Fehsenfeld, F. C., Goldan, P. D., Holloway, J. S., Kuster, W. C., Lerner, B. M., Matthew, B. M., Middlebrook, A. M., Onasch, T. B., Peltier, R. E., Quinn, P. K., Senff, C. J., Stohl, A., Sullivan, A. P., Trainer, M., Warneke, C., Weber, R. J., and Williams, E. J.: Sources of particulate matter in the northeastern United States in summer: 1. Direct emissions and secondary formation of or- 
ganic matter in urban plumes, J. Geophys. Res., 113, D08301, doi:10.1029/2007JD009243, 2008.

De Haan, D. O., Corrigan, A., Smith, K., Stroik, D., Turley, J. J., Lee, F., Tolbert, M., Jimenez, J., Codorva, K. E., and Ferrell, A.: Secondary organic aerosol-forming reactions of glyoxal with amino acids, Environ. Sci. Technol., 43, 2818-2848, 2009a.

De Haan, D. O., Tolbert, M. A., and Jimenez, J. L.: Atmospheric condensed-phase reactions of glyoxal with methylamine, Geophys. Res. Lett., 36, L11819, doi:10.1029/2009GL037441, 2009b.

De Haan D. O., Corrigan, A. L., Tolbert, M. A., Jimenez, J. L., Wood, S. E., and Turley, J. J.: Secondary organic aerosol formation by self-reactions of methylglyoxal and glyoxal in evaporating droplets, Environ. Sci. Technol., 43, 8184-8190, 2009c.

Donahue, N. M., Robinson, A. L., Stanier, C. O., and Pandis, S. N.: Coupled partitioning, dilution, and chemical aging of semivolatile organics, Environ. Sci. Technol., 40, 2635-2643, 2006.

El Haddad, I., Yao Liu, Nieto-Gligorovski, L., Michaud, V., Temime-Roussel, B., Quivet, E., Marchand, N., Sellegri, K., and Monod, A.: In-cloud processes of methacrolein under simulated conditions - Part 2: Formation of secondary organic aerosol, Atmos. Chem. Phys., 9, 5107-5117, doi:10.5194/acp-9-5107-2009, 2009.

Ervens, B., Carlton, A. G., Turpin, B. J., Altieri, K. E., Kreidenweis, S. M., and Feingold, G.: Secondary organic aerosol yields from cloud-processing of isoprene oxidation products, Geophys. Res. Lett., 35, L02816, doi:10.1029/2007GL031828, 2008.

Ervens, B., Feingold, G., Frost, G. J., and Kreidenweis, S. M.: A modeling study of aqueous production of dicarboxylic acids: 1 . Chemical pathways and speciated organic mass production, J. Geophys. Res., 109, D15205, doi:10.1029/2003JD004287, 2004.

Ervens, B. and Volkamer, R.: Glyoxal processing by aerosol multiphase chemistry: towards a kinetic modeling framework of secondary organic aerosol formation in aqueous particles, Atmos. Chem. Phys., 10, 8219-8244, doi:10.5194/acp-10-8219-2010, 2010.

Faust, B. C. and Allen, J. M.: Aqueous-phase photochemical formation of hydroxyl radical in authentic cloudwaters and fogwaters, Environ. Sci. Technol., 27, 1221-1224, 1993

Finlayson-Pitts, B. J. and Pitts Jr., J. N.: Chemistry of the upper and lower atmosphere, San Diego, Academic Press, 2000.

Fratzke, A. R. and Reilly, P. J.: Thermodynamic and kinetic analysis of the dimerization of aqueous glyoxal, Int. J. Chem. Kinet., 18, 775-789, 1986.

Fu, T-M., Jacob, D., and Heald, C. L.: Aqueous-phase reactive uptake of dicarbonyls as a source of organic aerosol over Eastern North America, Atmos. Environ., 43, 1814-1822, 2009.

Fu, T-M., Jacob, D. J., Wittrock, F., Burrows, J. P., Vrekoussis, M., and Henze, D. K.: Global budgets of atmospheric glyoxal and methylglyoxal, and implications for formation of secondary organic aerosols, J. Geophys. Res., 113, D15303, doi:10.1029/2007JD009505, 2008.

Gao, S., Ng, N., Keywood, M., Varutbangkul, V., Bahreini, R., Nenes, A., He, J., Yoo, K. Y., Beauchamp, J. L., Hodyss, R., Flagan, R. C., and Seinfeld, J.: Particle phase acidity and oligomer formation in secondary organic aerosol, Environ. Sci. Technol., 38, 6582-6589, 2004.

Galloway, M. M., Chhabra, P. S., Chan, A. W. H., Surratt, J. D.,
Flagan, R. C., Seinfeld, J. H., and Keutsch, F. N.: Glyoxal uptake on ammonium sulphate seed aerosol: reaction products and reversibility of uptake under dark and irradiated conditions, Atmos. Chem. Phys., 9, 3331-3345, doi:10.5194/acp-9-3331-2009, 2009.

Gelencser, A. and Varga, Z.: Evaluation of the atmospheric significance of multiphase reactions in atmospheric secondary organic aerosol formation, Atmos. Chem. Phys., 5, 2823-2831, doi:10.5194/acp-5-2823-2005, 2005.

Goldstein, A. H. and Galbally, I. E.: Known and unexplored organic constituents in the Earth's atmosphere, Environ. Sci. Technol., 41, 1514-1521, 2007.

Graber, E. R. and Rudich, Y.: Atmospheric HULIS: How humiclike are they? A comprehensive and critical review, Atmos. Chem. Phys., 6, 729-753, doi:10.5194/acp-6-729-2006, 2006.

Guzman, M. I., Colussi, A. J., and Hoffmann, M. R.: Photoinduced oligomerization of aqueous pyruvic acid, J. Phys. Chem. A., 110, 3619-3626, 2006.

Hastings, W. P., Koehler, C. A., Bailey, E. L., and De Haan, D. O.: Secondary organic aerosol formation by glyoxal hydration and oligomer formation: Humidity effects and equilibrium shifts during analysis, Environ. Sci. Technol., 39, 8728-8735, 2005.

Heald, C. L., Jacob, D. J., Park, R. J., Russell, L. M., Huebert, B. J., Seinfeld, J. H., Liao, H., and Weber, R. J.: A large organic aerosol source in the free troposphere missing from current models, Geophys. Res. Lett., 32, L18809, doi:10.1029/2005GL023831, 2005.

Hennigan, C. J., Bergin, M. H., Dibb, J. E., and Weber, R. J.: Enhanced secondary organic aerosol formation due to water uptake by fine particles, Geophys. Res. Lett., 35, L18801, doi:10.1029/2008GL035046, 2008.

Hennigan, C. J., Bergin, M. H., Russell, A. G., Nenes, A., and Weber, R. J.: Gas/particle partitioning of water-soluble organic aerosol in Atlanta, Atmos. Chem. Phys., 9, 3613-3628, doi:10.5194/acp-9-3613-2009, 2009.

Holt, T., Arey, J., and Atkinson, R.: Effect of water vapor concentration on the conversion of a series of 1,4-hydroxycarbonyls to dihydrofurans, J. Photochem. Photobio. A: Chem., 176, 231237, 2005.

Ip, H. S. S., Huang, X. H. H., and Yu, J. Z.: Effective Henry's law constants of glyoxal, glyoxalic acid, and glycolic acid, Geophys. Res. Lett., 36, L01802, doi;10.1029/2008GL036212, 2009.

Jang, M., Czoschke, N. M., Lee, S., and Kamens, M.: Heterogeneous atmospheric aerosol production by acid-catalyzed particlephase reactions, Science, 298, 814-817, 2002.

Jang, M. and Kamens, R. M.: Characterization of secondary aerosol from the photooxiadation of toluene in the presence of $\mathrm{NO}_{\mathrm{x}}$ and 1-propene, Environ. Sci. Technol., 35, 3626-3639, 2001.

Jimenez, J. L., Canagratna, M. R., Donahue, N. M., Prevot, A. S. H., Zhang, Q., Kroll, J. H., DeCarlo, P. F., Allan, J. D., Coe, J., Ng, N. L., Aiken, A. C., Docherty, K. S., Ulbrich, I. M., Grieshop, A. P., Robinson, A. L., Duplissy, J., Smith, J. D., Wilson, K. R., Lanz, V. A., Hueglin, C., Sun. Y. L., Tian, J., Laaksone, A., Raatikainen, T., Rautianen, J., Vaattovaara, P, Ehn, M., Kulmala, M., Tomlinson, J. M., Collins, D. R., Cubison, M. J., Dunlea, E. J., Huffman, J. A., Onasch, T. B., Alfarra, M. R., Williams, P. I., Bower, K., Kondo, Y., Schneider, J., Drewnick, F., Borrmann, S., Weimer, S., Demerjian, K., Slacedo, D., Cottrell, L., Griffin, R., Takami, A., Miyoshi, T., Hatakeyama, S., Shimono, A., Sun, J. 
Y., Zhang, Y. M., Dzepina, K., Kimmel, J. R., Sueper, D., Middlebrook, A. M., Kolb, C. E., Baltensperger, U., and Worsnop, D. R.: Evolution of organic aerosols in the atmosphere, Science, 326, 1525-1529, 2009.

Kalberer, M., Paulsen, D., Sax, M., Steinbacher, M., Dommen, J., Prevot, A. S. H., Fisseha, R., Weingartner, E., Frankevich, V., Zenobi, R., and Baltensperger, U.: Identification of polymers as major components of atmospheric organic aerosols, Science 303, 1659-1662, 2004.

Kiss, G., Tombacz, E., Varga, B., Alsberg, T., and Persson, L.: Estmation of the average molecular weight of humic-like substances isolated from fine atmsospheric aerosol, Atmos. Environ. 37, 3783-3794, 2003.

Kroll, J. H., Ng, N. L., Murphy, S. M., Varutbangul, V., Flagan, R. C., and Seinfeld, J. H.: Chamber studies of secondary organic aerosol growth by reactive uptake of simple carbonyl compounds, J. Geophys. Res., 110, D23207, doi:10.1029/2005JD006004, 2005.

Kroll, J. H., Ng, N. L., Murphy, S. M., Flagan, R. C., and Seinfeld, J. H.: Secondary organic aerosol formation from isoprene photooxidation, Environ. Sci. Technol., 40, 1869-1877, 2006.

Liggio, J., Li, S.-M., and McLaren, R.: Reactive uptake of glyoxal by particulate matter, J. Geophys. Res., 110, D10304, doi:10.1029/2004JD005113, 2005a.

Liggio, J., Li, S-M., and McLaren, R.: Heterogeneous reactions of glyoxal on particulate matter: Identification of acetals and sulfate esters, Environ. Sci. Technol., 39, 1532-1541, 2005b.

Lim, H. J., Carlton, A. G., and Turpin, B. J.: Isoprene forms secondary organic aerosol through cloud processing: model simulations, Environ. Sci. Technol., 39, 4441-4446, 2005.

Lim, Y. B. and Ziemann, P. J.: Products and mechanism of secondary organic aerosol formation from reactions of $n$-alkanes with $\mathrm{OH}$ radicals in the presence of $\mathrm{NO}_{\mathrm{x}}$, Environ. Sci. Technol., 39, 9229-9236, 2005.

Lim, Y. B. and Ziemann, P. J.: Effects of molecular structure on aerosol yields from $\mathrm{OH}$-radical initiated reactions of linear, branched, and cyclic alkanes in the presence of $\mathrm{NO}_{\mathrm{x}}$, Environ. Sci. Technol., 43, 2328-2334, 2009a.

Lim, Y. B. and Ziemann, P. J.: Kinetics of the heterogeneous conversion of 1,4-hydroxycarbonyls to cyclic hemiacetals and dihydrofurans on organic aerosol particles, Phys. Chem. Chem. Phys., 11, 8029-8039, 2009b.

Lim, Y. B. and Ziemann, P. J.: Chemistry of secondary organic aerosol formation from $\mathrm{OH}$ radical-initiated reactions of linear, branched, and cyclic alkanes in the presence of $\mathrm{NO}_{\mathrm{x}}$, Aerosol Sci. Technol. 43, 604-619, 2009c.

Loeffler, K. W., Koehler, C. A., Paul, N. M., and DeHann, D. O.: Oligomer formation in evaporating aqueous glyoxal and methyl glyoxal solutions, Environ. Sci. Technol., 40, 6318-6323, 2006.

Martin, P., Tuazon, E. C., Aschmann, S. M., Arey, J., and Atkinson, R.: Formation and atmospheric reactions of 4,5-dihydro-2methylfuran, J. Phys. Chem. A, 106, 11492-11501, 2005.

Monod, A., Poulain, L., Grubert, S., Voisin, D., and Wortham, H.: Kinetics of $\mathrm{OH}-$ initiated oxidation of oxygenated organic compounds in the aqueous phase: new rate constants, structureactivity relationships and atmospheric implications, Atmos. Environ., 39, 7667-7688, 2005.

Monod, A. and Doussin, J. F.: Structure-activity relationship for the estimation of $\mathrm{OH}$-oxidation rate constants of aliphatic or- ganic compounds in the aqueous phase: alkanes, alcohols, organic acids and bases, Atmos. Environ., 42, 7611-7622, 2008.

Munger, J. W., Collett, J., Daube Jr., B. C., and Hoffman, M. R. Fogwater chemistry at Riverside California, Atmos. Environ., 24, 185-205, 1990.

Myriokefalitakis, S., Vrekoussis, M., Tsigaridis, K., Wittrock, F., Richter, A., Brhl, C., Volkamer, R., Burrows, J. P., and Kanakidou, M.: The influence of natural and anthropogenic secondary sources on the glyoxal global distribution, Atmos. Chem. Phys., 8, 4965-4981, doi:10.5194/acp-8-4965-2008, 2008.

Noziere, B. and Cordova, A.: A kinetic and mechanistic study of the amino acid catalyzed aldol condensation of acetaldehyde in aqueous and salt solutions, J. Phys. Chem. A, 112, 2827-2837, 2008.

Nozière, B., Dziedzic, P., and Córdova, A.: Common inorganic ions are efficient catalysts for organic reactions in atmospheric aerosols and other natural environments, Atmos. Chem. Phys. Discuss., 9, 1-21, doi:10.5194/acpd-9-1-2009, 2009a.

Noziere, B., Dziedzic, P., and Cordova, A.: Products and kinetics of the liquid-phase of glyoxal catalyzed by ammonium ions $\left(\mathrm{NH}_{4}^{+}\right)$, J. Phys. Chem. A., 113, 231-237, 2009 b.

Noziere, B., Dziedzic, P., and Cordova, A.: Inorganic ammonium salts and carbonate salts are efficient catalysts for aldol condensation in atmospheric aerosols, Phys. Chem. Chem. Phys., 12, 3684-3872, 2010.

Odum, J. R., Hoffmann, T., Bowman, F., Collins, D., Flangan, R. C., and Seinfeld, J. H.: Gas/particle partitioning and secondary organic aerosol yields, Environ. Sci. Technol., 30, 2580-2585, 1996.

Pankow, J. F.: An absorption model of the gas/aerosol partitioning involved in the formation of secondary organic aerosol, Atmos. Environ., 28, 189-193, 1994.

Perri, M. J., Seitzinger, S., and Turpin, B. J.: Secondary organic aerosol production from aqueous photooxidation of glycoaldehyde: laboratory experiments, Atmos. Environ., 43, 1487-1497, 2009.

Perri, M., Lim, Y. B., Seitzinger, S. P., and Turpin, B. J.: Organosulfates from glycoladehyde in aqueous aerosols and clouds: Laboratory studies, Atmos. Environ., 44, 2658-2664, 2010.

Petters, M. D., Prenni, A. J., Kredenweis, S. M., DeMott, P. J., Matsunaga, A., Lim, Y. B., Ziemann, P. J.: Chemical aging and the hydrophobic-to-hydrophilic conversion of carbonaceous aerosol, Geophys. Res. Lett., 33, L24806, doi:10.1029/2006GL027249, 2006.

Polidori, A., Turpin, B. J., Davidson, C. I., Rodenburg, L. A., and Maimone, F.: Organic PM2.5: Fractionation by polarity, FTIR spectroscopy, and OM/OC ratio for the Pittsburgh Aerosol, Aerosol Sci. Technol., 42, 233-246, 2008.

Ravishankara, A. R.: Heterogeneous and multiphase chemistry in the troposphere, Science, 276, 1058-1065, 1997.

Robinson, A. L., Donahue, N. M., Shrivastava, M. K., Weitkamp, E. A., Sage, A. M., Grieshop, A. P., Lane, T. E., Pierce, J. R., and Pandis, S. N., Rethinking organic aerosols: Semivolatile emissions and photochemical aging, Science, 315, 1259-1262, 2007.

Saxena, P., Hildemann, L. M., McMurry, P., and Seinfeld, J. H.: Organics alter hygroscopic behavior of atmospheric particles, J. Geophys. Res., 100(D9) 18755-18770, 1995.

Sareen, N., Schwier, A. N., Shapiro, E. L., Mitroo, D., and McNeill, V. F.: Secondary organic material formed by methylglyoxal in 
aqueous aerosol mimics, Atmos. Chem. Phys., 10, 997-1016, doi:10.5194/acp-10-997-2010, 2010.

Schwier, A. N., Sareen, N., Mitroo, D., Shapiro, E. L., and McNeill, V. F., Glyoxal-methylglyoxal cross-reactions in secondary organic aerosol formation, Environ. Sci. Technol., 44, 6174-6182, 2010.

Schweighofer, K. J., Essmann, U., and Berkowitz, M.: Simulation of sodium dodecyl sulfate at the water - vapor and water - carbon tetrachloride interfaces at low surface coverage, J. Phys. Chem. B, 101, 3793-3799, 1997.

Seinfeld, J. H. and Pandis, S. N.: Atmospheric Chemistry and Physics, from Air Pollution to Climate Change, John Wiley \& Sons, New York, NY, 1998

Seinfeld, J. H. and Pankow, J. F.: Organic atmospheric particulate material, Ann. Rev. Phys. Chem., 54, 121-140, 2003.

Shapiro, E. L., Szprengiel, J., Sareen, N., Jen, C. N., Giordano, M. R., and McNeill, V. F.: Light-absorbing secondary organic material formed by glyoxal in aqueous aerosol mimics, Atmos. Chem. Phys., 9, 2289-2300, doi:10.5194/acp-9-2289-2009, 2009.

Stefan, M. I. and Bolton, J. R.: Mechanism of the degradation of 1,4-dioxane in the dilute aqueous solution using the UV/hydrogen peroxide process, Environ. Sci. Technol., 32, 1588-1595, 1998.

Stefan, M. I. and Bolton, J. R.: Reinvestigation of the acetone degradation mechanism in dilute aqueous solution by the $\mathrm{UV} / \mathrm{H}_{2} \mathrm{O}_{2}$ process, Environ. Sci. Technol., 33, 870-873, 1999.

Sun, Y. L., Zhang, Q., Anastasio, C., and Sun, J.: Insights into secondary organic aerosol formed via aqueous-phase reactions of phenolic compounds based on high resolution mass spectrometry, Atmos. Chem. Phys., 10, 4809-4822, doi:10.5194/acp-104809-2010, 2010.

Sullivan, A. P. and Weber, R. G.: Chemical characterization of the ambient organic aerosol soluble in water: 1 . Isolation of hydrophobic and hydrophilic fractions with XAD-8 resin, J. Geophys. Res., 111, D05314, doi:10.1029/2005JD006485, 2006.

Surratt, J. D., Murphy, S. M., Kroll, J. H., Ng, N. L., Hildebradt, L., Sorooshian, A., Szmigielski, R., Vermeylen, R., Maenhaut, W., Claeys, M., Flagan, R., and Seinfeld, J. H.: Chemical composition of secondary organic aerosol formed form the photooxidation of isoprene, J. Phys. Chem. A, 110, 9665-9690, 2006.

Surratt, J. D., Kroll, J. H., Kleindienst, T., E., Edney, E. O., Claeys, M., Sorooshian, A., Ng, N. L., Offenberg, J. H., Lewandowski, M., Jaoui, M., Flagan, R., and Seinfeld, J. H.: Evidence for organosulfates in secondary organic aerosol, Environ. Sci. Technol., 41, 517-527, 2007.

Tadic, J., Moortgat, G. K., and Wirtz, K.: Photolysis of glyoxal in air, J. Photochem. Photobiol. A: Chem., 177, 116-124, 2006.

Tan, Y., Perri, M. J., Seitzinger S. P., and Turpin, B. J.: Effects of precursor concentration and acidic sulfate in aqueous glyoxal$\mathrm{OH}$ radical oxidation and implications for secondary organic aerosol, Environ. Sci. Technol., 43, 8105-8112, 2009.

Tolocka, M. P., Jang, M. Ginter, J. M., Cox, F. J., Kamens, R. M., and Johnston, M. V.: Formation of oligomers in secondary organic aerosol, Environ. Sci. Technol., 38, 1428-1434, 2004.

Tsigaridis, K. and Kanakidou, M.: Global modelling of secondary organic aerosol in the troposphere: a sensitivity analysis, Atmos. Chem. Phys., 3, 1849-1869, doi:10.5194/acp-3-1849-2003, 2003.

Turpin, B. J. and Lim H. J.: Species contributions to PM2.5 mass concentrations: Revisiting common assumptions for estimating organic mass, Aerosol Sci. Technol., 35, 602-610, 2001.

Varutbangkul, V., Brechtel, F. J., Bahreini, R., Ng, N. L., Keywood, M. D., Kroll, J. H., Flagan, R. C., Seinfeld, J. H., Lee, A., and Goldstein, A. H.: Hygroscopicity of secondary organic aerosols formed by oxidation of cycloalkenes, monoterpenes, sesquiterpenes, and related compounds, Atmos. Chem. Phys., 6, 23672388, doi:10.5194/acp-6-2367-2006, 2006.

Volkamer, R., Barnes, I., Platt, U., Molina, L. T., and Molina, M. J.: Primary and secondary glyoxal formation from aromatics: experimental evidence for the bicycloalkyl-radical pathway from benzene, toluene, and p-xylene, J. Phys. Chem. A, 105, 78657874, 2001.

Volkamer, R., Molina, L. T., and Molina, M. J.: DOAS measurement of glyoxal as an indicator for fast VOC chemistry in urban air, Geophys. Res. Lett., 32, L08806, doi:10.1029/2005GL022616, 2005.

Volkamer, R., San Martini, F., Molina, L. T., Salcedo, D., Jimenez, J. L., and Molina, M. J.: A missing sink for gas-phase glyoxal in Mexico City: Formation of secondary organic aerosol, Geophys. Res. Lett., 34, L19807, doi:10.1029/2007GL030752, 2007.

Volkamer, R., Ziemann, P. J., and Molina, M. J.: Secondary Organic Aerosol Formation from Acetylene $\left(\mathrm{C}_{2} \mathrm{H}_{2}\right)$ : seed effect on SOA yields due to organic photochemistry in the aerosol aqueous phase, Atmos. Chem. Phys., 9, 1907-1928, doi:10.5194/acp9-1907-2009, 2009.

Wang, W. F., Schuchmann, M. N., Schuchmann, H. P., and von Sonntag, C.: The importance of mesonmerism in the termination of alpha-carboxymethyl radicals from aqueous malonic and acetic acids, Chem. Eur. J., 7, 791-795, 2001.

Warneck, P.: The relative importance of various pathways for the oxidation of sulfur dioxide and nitrogen dioxide in sunlit continental fair weather clouds, Phys. Chem. Chem. Phys., 1, 54715483, 1999.

Warneck, P.: In-cloud chemistry opens pathway to the formation of oxalic acid in the marine atmosphere, Atmos. Environ., 37, 2423-2427, 2003.

Weber, R., Sullivan, A. P., Peltier, R. E., Russell, A., Yan, B., Zheng, M., de Gouw, J., Warnecke, C., Brock, C., Holloway, J., S., Atlas, E. L., and Edgerton, E.: A study of secondary organic aerosol formation in the anthropogenicinfluenced southeastern United States, J. Geophys. Res., 112, D13302, doi:10.1029/2007JD008408, 2007.

Yasmeen, F., Sauret, N., Gal, J. F., Maria, P.-C., Massi, L., Maenhaut, W., and Claeys, M.: Characterization of nonphotochemically formed from methylglyoxal: a pathway to produce secondary organic aerosol through cloud processing during night-time, Atmos. Chem. Phys. Discuss., 9, 22993-23020, 2009 , http://www.atmos-chem-phys-discuss.net/9/22993/2009/.

Zhang, R., Suh, I., Zhao, J., Zhang, D., Fortner, E. C., Tie, X., Molina, L. T., and Molina, M. J.: Atmospheric new particle formation enhanced by organic acid, Science, 304, 1487-1490, 2004.

Zhang, R., Wang, L., Khalizov, A. F., Zhao, J., Zheng, J., McGraw, R. L., and Molina, L. T.: Formation of nanoparticles of blue haze enhanced by anthropogenic pollution, P. Natl. Acad. Sci. USA, 106, 17650-17654, 2009.

Zhang, Q., Jimenez, J. L., Canagaratna, M. R., Allan, J. D., Coe, 
H., Ulbrich, I., Alfarra, M. R., Takami, A., Middlebrook, A. M., Sun, Y. L., Dzepina, K., Dunlea, E., Docherty, K., DeCarlo, P. F., Salcedo, D., Onasch, T., Jayne, J. T., Miyoshi, T., Shimono, A., Hatakeyama, S., Takegawa, N., Kondo, Y., Schneider, J., Drewnick, F., Weimer, S., Demerjian, K., Williams, P., Bower, K., Bahreini, R., Cottrell, L., Griffin, R. J., Rautiainen, J., and Worsnop, D. R.: Ubiquity and dominance of oxygenated species in organic aerosols in anthropogenicallyinfluenced northern hemisphere mid-latitudes, Geophys. Res. Lett., 34, L13801, doi:10.1029/2007GL029979, 2007.
Zhao, J., Levitt, N. P., Zhang, R., and Chen, J.: Heterogeneous reactions of methylglyoxal in acidic media: Implications for secondary organic aerosol formation, Environ. Sci. Technol., 40, 7682-7687, 2006.

Zhou, X. L. and Mopper, K.: Apparent partition-coefficients of 15 carbonyl-compounds between air and seawater and between air and fresh-water - implications for air sea exchange, Environ. Sci. Technol., 24, 1864-1869, 1990. 